\title{
MicroRNAs: Diverse Mechanisms of Action and Their Potential Applications as Cancer Epi-Therapeutics
}

\author{
Anna Sadakierska-Chudy \\ Department of Genetics, Faculty of Medicine and Health Sciences, \\ Andrzej Frycz Modrzewski Krakow University, 30-705 Krakow, Poland; asadakierska-chudy@afm.edu.pl
}

Received: 2 July 2020; Accepted: 2 September 2020; Published: 7 September 2020

\begin{abstract}
Usually, miRNAs function post-transcriptionally, by base-pairing with the $3^{\prime} U T R$ of target mRNAs, repressing protein synthesis in the cytoplasm. Furthermore, other regions including gene promoters, as well as coding and $5^{\prime}$ UTR regions of mRNAs are able to interact with miRNAs. In recent years, miRNAs have emerged as important regulators of both translational and transcriptional programs. The expression of miRNA genes, similar to protein-coding genes, can be epigenetically regulated, in turn miRNA molecules (named epi-miRs) are able to regulate epigenetic enzymatic machinery. The most recent line of evidence indicates that miRNAs can influence physiological processes, such as embryonic development, cell proliferation, differentiation, and apoptosis as well as pathological processes (e.g., tumorigenesis) through epigenetic mechanisms. Some tumor types show repression of tumor-suppressor epi-miRs resulting in cancer progression and metastasis, hence these molecules have become novel therapeutic targets in the last few years. This review provides information about miRNAs involvement in the various levels of transcription and translation regulation, as well as discusses therapeutic potential of tumor-suppressor epi-miRs used in in vitro and in vivo anti-cancer therapy.
\end{abstract}

Keywords: Ago; DNMT inhibitor; epi-miRs; HDAC; lncRNA; virial vector

\section{Introduction}

Although research into RNA biology has been ongoing for more than two decades, almost each year brings new discoveries. Until recently, it was thought that microRNAs (miRNAs) act mainly in the cytoplasm at the post-transcriptional level. Interestingly, miRNAs can exert regulatory effect both in the cell (i.e., cytoplasm and nucleus) in which they are produced and in neighboring cells. The latter intracellular transfer of miRNA is mediated by gap junction channels or exosomes [1]. Interestingly, mature miRNAs can regulate one or more mRNA targets, but also a single mRNA transcript can be bound and regulated by many different miRNAs. It is estimated that each miRNA can recognize 100-200 target sites of the transcriptome and the inhibitory effect on expression can be achieved at 1000 copies per cell [1,2]. miRNAs can recognize and bind to $3^{\prime}$ UTR, $5^{\prime}$ UTR and coding sequence of their targets' mRNA, as well as to promoter regions. Considering miRNAs variety and localization, cell type and cell state, their possibilities to regulate gene expression are limitless.

\section{Inhibition or Activation of Translation}

Mature miRNAs (mainly guide strands) form a complex with Argonaut (AGO) proteins called miRNA-induced silencing complex (miRISC) which interact with other proteins including DICER, TRBP, PACT and GW182. The miRNA specific region called 'seed sequence' (which includes nucleotides between 2 and 8 , counting from the $5^{\prime}$ end of the miRNA) base-pairs with miRNA recognition elements 
(MREs) located on mRNA targets. miRISC complex binding to 3'UTR leads to mRNA cleavage or mRNA decay and finally translation inhibition. For example, full complementarity of the seed region to MRE induces AGO-2 endonuclease activity resulting in mRNA cleavage and destabilization of AGO2-miRNA interaction that ultimately promotes miRNA degradation [3,4]. In contrast, incomplete complementarity prevents AGO-2 endonuclease activity but initiates the recruitment of GW182 protein family leading to mRNA decay. GW182 interacts with PABPC (polyadenylate-binding protein) that promotes efficient mRNA deadenylation by recruiting poly(A)-deadenylase complexes (PAN2-PAN3 and CCR4-NOT). Subsequently, mRNA-decapping enzymes (DCP1-DCP2) recognize and remove the $5^{\prime}$-cap from mRNA transcripts making mRNA susceptible to degradation by $5^{\prime}-3^{\prime}$ exoribonuclease 1 (XRN1) [5,6]. A recent study has revealed that mRNA decay is responsible for a large majority (66-90\%) of miRNA-mediated translation repression [7]. Moreover, miRISC can inhibit translation at the initiation step probably through dissociation of eukaryotic initiation factors 4A (eIFA4-I and eIFA4-II) making it difficult for ribosome scanning and assembly of the eIF4F translation initiation complex $[8,9]$.

In addition, miRNAs can also bind to target sites in the coding region and inhibit translation. Probably, target sequences in the coding regions are used when the $3^{\prime}$ UTR are too short or adjust to protein abundance of alternative splice variants [10]. For example, Cardinali et al. have identified that the $A H N A K$ gene contains a miR-222 target sequence within the coding region hence miR-222 can directly down-regulate its expression [11]. Additionally, a study by Splengler et al. has revealed an abundance of miRNA target sites in gene coding regions [12].

Surprisingly, some studies have reported that miRNAs binding to $3^{\prime} \mathrm{UTR}$ or $5^{\prime} \mathrm{UTR}$ regions can up-regulate gene expression by increasing translation rates of proteins.

It was demonstrated that translation activation can depend on the cell cycle state and proteins that are bound to the AGO2-miRNA complex within the 3'UTR. Indeed, in serum starved cells Fragile-X-mental retardation related protein 1 (FXR1) was recruited by the AGO2-miRNA complex associated with AU-rich elements (AREs) at the 3'UTR and activated translation [13]. The miRNA-mediated activation of transcription has been observed also in other quiescent cells, such as immature oocytes of the Xenopus (e.g., Myt1 mRNA via AGO-miR16-FXR1 complex) [14].

Furthermore, it was revealed that miRNAs that bind to the $5^{\prime}$ UTR can enhance translation through various mechanisms. For example, liver specific miR-122 binding to RNA of hepatitis $C$ virus protects the single-stranded $5^{\prime}$ end from cytosolic exonuclease activities (increasing RNA stability against Xrn1) and enhances the recruitment of ribosomes as well as possibly providing a scaffold for binding of other essential factors for translation [15-18]. Another example is $m i R-10 a$ that interacts with the $5^{\prime}$ terminal oligopyrimidine (5'TOP) motif of ribosomal protein mRNAs and enhance their translation during amino acid starvation [19]. Moreover, miR-346, produced mostly in brain tissues, binds to $5^{\prime}$ UTR of the receptor interacting protein 140 (RIP140) mRNA facilitating its association with the polysomes and finally activating translation via an AGO2-independent manner [20].

\section{Suppression or Enhancement of Transcription}

Surprisingly, studies have shown bidirectional transport of the core components of miRNA silencing machinery. It was demonstrated that several proteins including Importin- 8 , Importin $\alpha / \beta$ $(\operatorname{Imp} \alpha / \operatorname{Imp} \beta)$ and Exportin-1 (XPO1) mediate shuttling of key RISC components from the cytoplasm to the nucleus, moreover, XPO1 is able to transport the nuclear RISC (miRNA-Ago-TNRC6A complex) to the cytoplasm $[21,22]$.

On the one hand, TNRC6A protein, also known as GW182, can be independently transported into the nucleus binding directly to $\operatorname{Imp} \beta$ and interacting with $\operatorname{Imp} \alpha[23,24]$. On the other hand, TNRC6A facilitates the shuttling of miRNA containing AGO-2 into the nucleus via its own nuclear localization signal sequence [25]. Besides, AGO-2 can be imported into the nucleus via IPO8 only when it loads mature miRNA [26]. Figure 1 illustrates the different ways of delivering RISC proteins and miRNAs from the cytoplasm into the nucleus. 


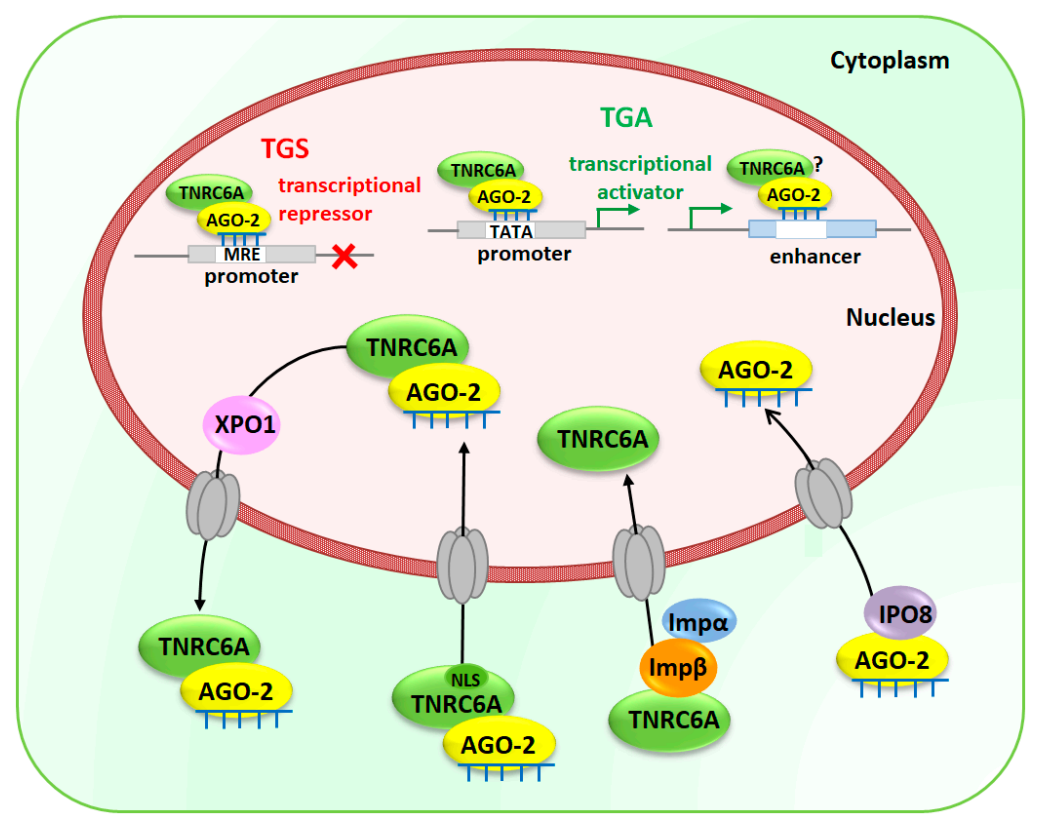

Figure 1. Transport of mature miRNAs and components of RISC (RNA-induced silencing complex) into the nucleus. TNRC6A is shuttled from the cytoplasm into the nucleus either via its own NLS sequence when it interacts with miRNA-AGO complex or independently via its interaction with Importin $\beta(\operatorname{Imp} \beta)$ and Importin $\alpha(\operatorname{Imp} \alpha)$. While mature miRNAs loaded into AGO-2 are translocated into the nucleus by Importin 8 (IPO8) miRNA-AGO-TNRC6A complex can be exported back to the cytoplasm by Exportin 1 (XPO1). In the nucleus, miRISC will interact with promoters or enhancers leading to transcriptional gene silencing (TGS) or transcriptional gene activation (TGA). The putative miRNA recognition elements (MREs) could be recognized by miRNAs that mediate chromatin silencing complex assembly or de novo DNA methylation at the promoter region resulting in compact, silent heterochromatin and TGS. Unlike, when miRISC interacts with TATA-box motifs enhancing promoter activities leading to TGA through enrichment of chromatin-remodeling factors and active chromatin marks. Moreover, miRNAs interaction with enhancers result in TGA through chromatin remodeling and the enrichment of active marks at enhancer regions. NLS-nuclear localization signal sequence.

Moreover, it is proposed that miRNA nuclear localization can also be controlled by nuclear localization signal sequences in miRNA molecules or full processing of pre-miRNAs in the nucleus. Several studies show that various motifs, including AGUGUU-motif, 5'-UUGCAUAGU-3' and 5'-AGGUUGKSUG-3' motifs (where $\mathrm{K}$ is a uridine or a guanine) as well as the consensus ASUS sequence (where $S$ is a cytosine or a guanidine) are presented in many miRNAs and are engaged in the nuclear translocation [27-29]. It is supposed that miRNAs translocation is controlled by RNA-binding proteins (RBPs), however, molecular pathways are now recognized. Regarding processing of pre-miRNA molecules and their loading into nuclear RISC complex, there are many uncertainties that need to be investigated.

Although the functions of nuclear miRNAs have not been fully elucidated, it is suggested that they can regulate both transcriptional rates and post-transcriptional levels of mRNAs. miRNA-promoter interaction mediated by AGO proteins may either suppress or activate transcription depending on the location of their target region and epigenetic status of the promoter [22,30]. Genome-wide analysis revealed that human promoters contain miRNA-seed matching sites, suggesting that miRNA-mediated transcription regulation is likely to be a common phenomenon [31]. On the one hand, Benhamed et al. demonstrated that AGO-2 and let-7f are involved in the transcriptional repression of proliferation-promoting genes regulated by the retinoblastoma $(\mathrm{Rb}) / \mathrm{E} 2 \mathrm{~F}$ repressor complex in senescence [32]. The putative MREs for the let-7f have been localized in the promoters of two E2F-target genes $C D C 2$ and $C D C A 8$. Similarly, nuclear miR-522 suppresses transcription of CYP2E1 gene by 
interacting with its promoter forming a DNA:RNA hybrid which probably prevents binding of Pol II and transcription factor [33]. On the other hand, Zhang et al. revealed that several miRNAs, such as let-7i, miR-138, miR-92a and miR-181d bind to the TATA-box motifs and enhance the promoter activities of interleukin-2, insulin, calcitonin or c-Myc, respectively [34]. Also, Cyclin B gene has a sequence located in its promoter that interacts with $m i R-744-5 p$ and $m i R-466 d-3 p$ leading to transcriptional upregulation [35]. A recent study has revealed, that miRNAs (miR-26a-1, miR-339, miR-3179, miR-24-1 and $m i R-24-2)$ are able to induce expression of neighboring genes and function as enhancer (cis-acting DNA elements) regulators [36]. Moreover, this study has also shown that miR-24-1 (located in the enhancer region) increases expression of FBP1 and FANCC genes and triggers direct chromatin state alteration of the FBP1 enhancer that activate transcription. Another notable fact is that transcriptional gene silencing (TGS) and transcriptional gene activation (TGA) can be achieved by miRNA-mediated epigenetic regulation. Indeed, miRNA directs the RNA-induced transcriptional silencing complex (RITS), which consists of chromatin remodeling enzymes (e.g., HDAC1, EHMT2 and EZH2) and DNA methyltransferase (DNMT3A), to promoter leading to the transition of active chromatin structure to silent heterochromatin [31]. According to the study carried out by Kim and co-workers miR-320 directs to the promoter region AGO-1 that acts as the effector protein for transcriptional silencing of POLR3D gene [37]. Furthermore, simultaneous enrichment of tri-methyl histone H3 lysine 27 (H3K27me3, a repressive chromatin mark) and $\mathrm{EZH} 2$, a histone methyltransferase that mediates $\mathrm{H} 3 \mathrm{~K} 27 \mathrm{me} 3$, has been observed at the POLR3D promoter [37]. Another study has revealed that miR17-5p and miR20a, encoded within a poly-miRNA cluster $m i R-17-92$, are involved in the acquisition of heterochromatin marks at the promoters through seed-paring manner [38]. miRNA-mediated TGS is involved in cell differentiation processes. For example, during granulopoiesis miR-223-RISC interaction with the promoter of nuclear factor I-A (NFI-A) results in the recruitment of Polycomb group complex and histone-modifying enzymes that repress transcription of NFI-A, an important step for granulocytic differentiation [39]. It is postulated that specific miRNA can initiate TGS through de novo DNA methylation or chromatin modification in human cancer cells. In fact, miR-10a with AGO-1 and AGO-3 reduces HOX4 expression in human breast cells mediating in de novo DNA methylation and accumulation of repressive chromatin marks (H3K27me3 and H3K9me2, di-methyl histone H3 lysine 9) at its promoter [40].

In contrast, AGO-miRNA complex may activate the expression of target loci by either disruption of the recruitment of silencing proteins (e.g., PRC2) to lncRNAs (long non-coding RNAs) or recruitment of protein complex containing transcriptional activators (e.g., transcription factors) [31,41]. In the nucleus, lncRNAs regulate epigenetic silencing of adjacent genes through recruiting chromatin-remodeling factors in close proximity of their promoters [42]. In case of miR-744 and Ccnb1 gene, miRNA-mediated TGA rely on the recruitment of AGO proteins and RNA Pol II enrichment as well as active chromatin marks (such as H3K4me3, tri-methyl histone H3 lysine 4) at the regulated gene promoters [35]. Moreover, miR-373 activates transcription of E-cadherin and CSDC2 genes only via enrichment of RNA Pol II at their promoters [43], while miR-205 induces the expression of IL24 and IL32 tumor suppressor genes by targeting specific sites in their promoters as well enrichment of RNA Pol II and active chromatin modifications [44].

Similar to cytoplasmic miRNAs, nuclear miRNAs can also mediate post-transcriptional gene silencing (PTGS) inducing degradation of target mRNAs. Several studies suggest that miRNAs contribute to the regulation of miRNA precursors and lncRNA transcripts [31]. For instance, mouse nuclear miR-709 is involved in the post-transcriptional regulation of the pri-miR-15a/miR-16-1, binding to a 19-nt recognition element and preventing processing of primary transcripts, thus, nuclear miRNAs can influence the biogenesis of other miRNAs suggesting hierarchical structures among miRNAs [45]. Furthermore, some nuclear-retained lncRNAs are also regulated by AGO-miRNA complexes that interact with miRNA-complementary sequences located in lncRNAs, thus impairing their stability and function [42]. Indeed, the highly abundant lncRNA, metastasis associated lung adenocarcinoma transcript 1 (MALAT1), has two MRE's which are recognized and bound by miR-9 [46]. Subsequently, 
putative miR-675-5p binding site within H19 RNA transcripts has been identified and the overexpression of miR-675-5p significantly downregulated the level of the $H 19$ transcript [47]. So far, several other non-coding RNAs directly targeted by miRNAs have been identified. Interestingly, a long non-protein coding RNA involved in mammalian X-chromosome inactivation, $X$ (inactive)-specific transcript (XIST), has seed-paring sites for miR-210 which modulates its RNA level [48]. Additionally, miR-671 directs AGO2-mediated cleavage of a circular antisense transcript of the CDR1 gene and negatively regulates this non-coding antisense transcript [49].

\section{Regulation of Alternative Splicing}

miRNAs are able to indirectly modulate alternative splicing by regulating translation of various splicing factors. However, mounting evidence suggests that AGO-miRNA complexes can affect the regulation of alternative splicing directly in the nucleus by epigenetic and non-epigenetic mechanisms. A co-immunoprecipitation study has identified multiple AGO-associated splicing factors, moreover, AGO-1, AGO-2 and DICER1 knockdown and overexpression experiments confirmed their involvement in splicing decisions at alternatively spliced exons [50,51]. Advanced molecular analyses were able to identify miRNA binding sites within intronic sequences in mouse and human brain as well as in human myocardial cells $[12,52,53]$. It is proposed that miRNAs-mediated compaction of chromatin structure at specific exon-intron junctions slows the rate of RNA Pol II elongation, which favors exon inclusion [54]. Surprisingly, exon skipping can be achieved by single-stranded oligonucleotides (ss-siRNA), ss-siRNA is incorporated by AGO-2 in the cytoplasm, then is transported into the nucleus where AGO2-ss-siRNA complex binds to the target mRNA and disrupts association with the splicing machinery [55].

Taken together, the above considerations illustrate the complex regulatory mechanisms of miRNA-mediated gene expression in the cytoplasm and the nucleus. It should be emphasized, that miRNAs are involved in many crucial cellular regulatory processes and may activate or inhibit gene expression at both transcriptional and post-transcriptional level. Thus, deregulation of miRNAs biogenesis and function can disrupt these processes and finally lead to a wide range of human diseases. Hence, miRNAs are valuable as diagnostic and prognostic biomarkers for many diseases, including cancer, diabetes mellitus, cardiovascular pathologies and neurological disorders. Moreover, miRNAs are considered as molecular targets of novel therapies and treatment strategies.

\section{4. miRNAs As Potential Cancer Epi-Therapeutics}

Over the past few decades growing evidence has linked epigenetic mechanisms with the regulation of gene expression. Epigenetic markers such as DNA methylation and post-translational modifications of histone tails can rearrange the structure of chromatin leading either to activation or repression of transcription activity (for details see reviews $[56,57]$ ). It is interesting that not only nucleotide sequences determine the level of gene expression but also epigenetic modifications are involved in this process. Epigenetic processes are orchestrated by multiple proteins (e.g., DNA methyltransferases, DNA demethylases and histone modifying enzymes), non-coding RNAs (e.g., miRNAs and lncRNAs) and environmental factors. Typically, loss of DNA methylation (hypomethylation) turns on gene transcription by altering the structure of chromatin. In turn, too much DNA methylation (hypermethylation) induces chromatin compaction and hinders the expression of genes. Therefore, disruption of epigenetic regulation can lead to inappropriate gene expression that impairs crucial biological processes resulting in the development of "epigenetic diseases". The first "epigenetic disease" was cancer and it was established that patients with colorectal cancer had less DNA methylation levels in cancer tissues than from their normal tissue [58]. Growing evidence suggests that epigenetic changes, unlike DNA sequence mutations, are reversible, so it seems that these changes can be an ideal target for epigenetic treatments.

Recently, a subclass of miRNAs, referred to as epi-miRNAs, that influence the expression of genes encoding epigenetic effector and reader proteins, has been identified [59]. Due to the important role of epi-miRs in the modulation of the epigenome, they are currently considered as 
potential therapeutic targets, especially in cancer. Manipulation of epi-miRs can affect the expression of epigenetically-regulated genes, such as oncogenes and/or tumor suppressor genes, involved in important cellular pathways including DNA replication, cell cycle progression and apoptosis $[60,61]$. The two types of miRs, oncomiRs and tumor-suppressor miRs, can be distinguished regarding their role in carcinogenesis. Generally, oncomiRs are up-regulated thereby increasing cancer cell proliferation and metastasis, in contrast the expression of tumor-suppressor miRs are down-regulated leading to enhanced tumorigenesis [62]. In this review, we focus on the therapeutic potential of tumor-suppressor epi-miRs that are downregulated in various types of cancer (casi el tinc. Emerging studies found that the decreased levels of epi-miRs promote cell proliferation, colony formation, tumor growth and metastasis [62-64]. Moreover, the suppression of some epi-miRs are responsible for the drug resistance of cancer cells [64,65]. Schematic relationship between downregulated tumor-suppressor epi-miRs, chromatin-modifying enzymes and cellular processes is shown in Figure 2.

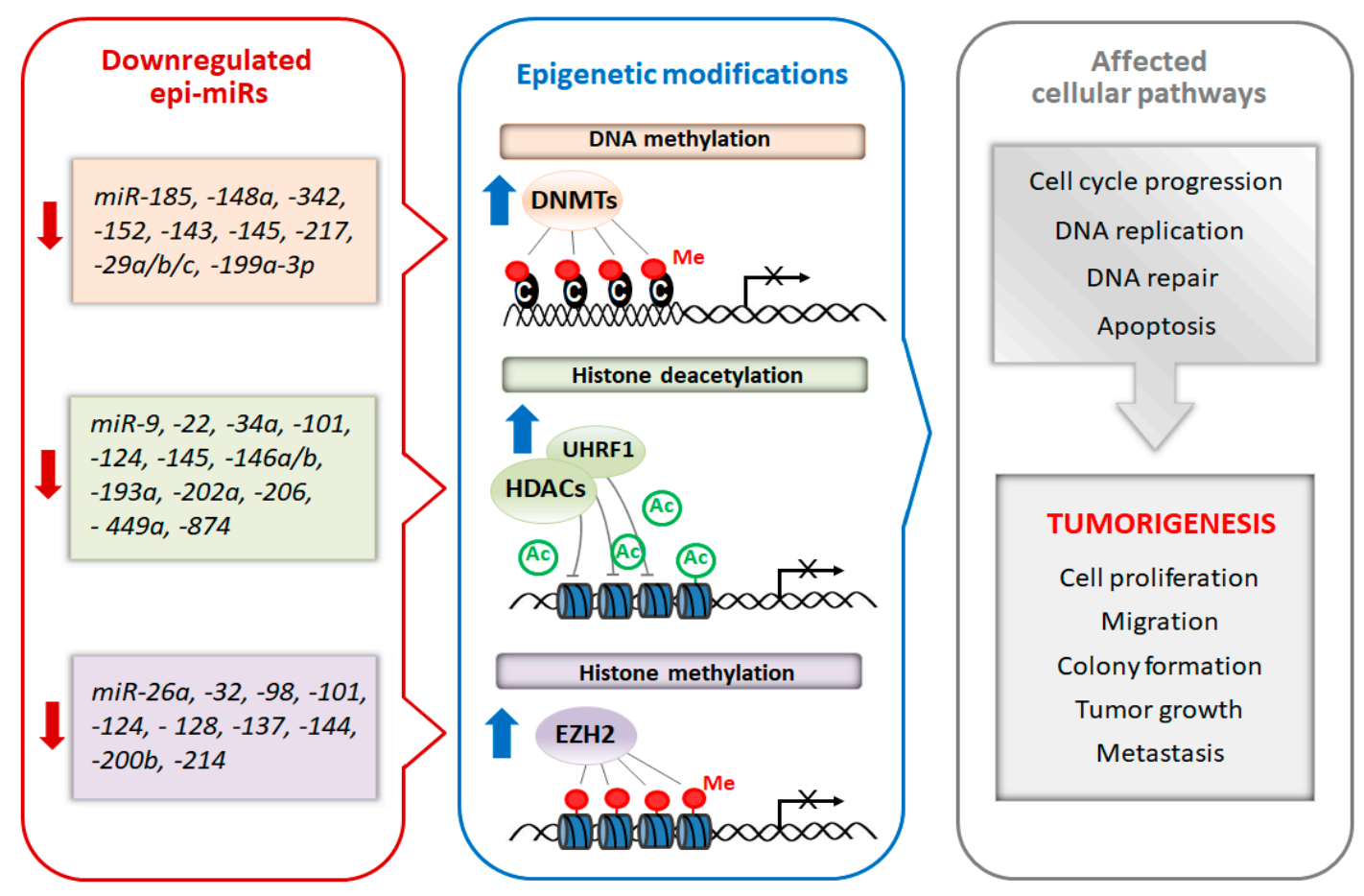

Figure 2. Schematic diagram of epi-miRs involved in the regulation of epigenetic modifiers and tumorigenesis. Suppression of miRNAs that regulate chromatin-remodeling enzymes lead to their overexpression. In turn epigenetic dysregulation resulting in improper regulation of genes responsible for different cell processes including cell proliferation, DNA repair and apoptosis thus triggering tumorigenesis.

To date, several causes have been found that influence the activity of miRNAs, their down-regulation is coupled with epigenetic silencing or genomic abnormalities, such as gene amplification, deletions and microdeletions (e.g., at miR-101-1 loci) as well as mutations and chromosomal rearrangements [66,67]. Considering, the drug resistance of cancer chemotherapy (i.e., doxorubicin, cisplatin, paclitaxel), which are related to down-regulation of epi-miRs, their enforced expression appears to be an interesting approach to restore drug sensitivity (Table 1). Fabbri and co-workers revealed that the miR-29 family $(29 a,-b$, and $-c)$ act as tumor suppressor miRs in lung cancer and regulate transcript levels of DNMT3A and DNMT3B [68]. Moreover, it has been established that synthetic epi-miR, miR-29b oligonucleotides, potentiates a hypomethylating effect of DNMT1 inhibitors (decitabine or azacitidine) resulting in better AML response for treatment probably due to the inhibition of other DNMT isoforms that are not efficiently suppressed by these agents [69]. Another study showed that synthetic miR-29b mimics inhibit HDAC4 expression in multiple myeloma 
cell lines, reduce migration potential and increase apoptosis, therefore, this approach could offer a novel targeted therapy [70]. In addition, a recent study has shown that $m i R-148 a$ combination therapy with either cisplatin or doxorubicin significantly enhanced apoptosis in urothelial cell carcinoma of the bladder cell lines [71]. Importantly, cancer stem cells (CSCs) are characterized by their ability to self-renew and resistance to standard chemotherapy, during remission can regenerate a tumor identical to the original one. An elegant study by Iliopoulos and colleagues uncovered that the combinatorial therapy of doxorubicin with epi-miR (miR-200b) was more effective than doxorubicin alone, blocking tumor growth and preventing relapse [72]. Interestingly, many natural agents, such as resveratrol, curcumin and glabridin used for epigenetic therapy, among others, exert their potent anti-tumor effects by enhancing expression of epi miRs. For instance, resveratrol causes up-regulation of $m i R-137$ in neuroblastoma tumors [73], curcumin increases levels of $m i R-29 a$ and $m i R-185$ in hepatocellular cancer cells [74], in turn glabridin potentiates expression of $m i R-148 a$ in breast cancer cells [75].

Epi-miRs-targeted cancer therapy seems to be a promising approach since it is able to influence not only a single gene, but multiple pathways. It is possible to re-establish expression of epi-miRs by delivering synthetic miR mimics (double stranded RNA oligonucleotides directly loaded into RISC) or chemically modified poly(nucleic acids), however, cellular uptake of free synthetic miRs are limited because of the ease in which they a degraded in biofluids [76]. In order to overcome poor in vivo stability and improve efficient and specific-site delivery of miRs to the tumor, innovative delivery systems are required. Currently, both viral and non-viral systems are used to increase stability of miRNA oligonucleotides and enhance their therapeutic effect. Administration of epi-miRs via viral vectors (e.g., adenoviruses, adeno-associated viruses (AAV) or lentiviruses) is very effective, as shown by systemic intravenous injection of epi-miR, $m i R-26 a$, packaged into AAV vector, which inhibited progression of hepatocellular carcinoma in a mouse model [77]. However, due to the viral vectors possible toxicity and immunogenicity their use in clinical practice is limited. In this context, non-viral systems seem to be more promising, because of the control of their molecular composition, ease in manufacturing and relatively low immunogenicity. Different delivery systems including, lipid-based delivery system, synthetic polymers (e.g, polyethyleneimine (PEI)) and naturally occurring polymers (e.g., chitosan, protamine and atelocollagen) are applied to protect miRs from degradation (for details see the review [78]). For example, a novel transferrin-conjugated nanoparticle delivery system for synthetic epi-miR, miR-29b, was injected intravenously and significantly prolonged leukemic mice survival [79]. Despite significant advances made in delivery systems of miRs, substantial improvements will be necessary for achieving site-specific delivery.

The discovery of therapeutic epi-miRs potential in cancer therapy makes them attractive candidates for next-generation cancer treatment. It therefore seems likely that profiling of miRs expression and then using appropriate epi-miR-based therapeutics may revolutionize cancer treatment by enabling the reversal of the epigenetic program of tumor cells to a more normal state.

However, we realize that turning epi-miR-based therapy into clinical practice faces challenges. Indeed, some clinical trials with miRNA drugs have not always produced satisfactory results. For example, the FDA (Food and Drug Administration) halted phase I clinical trial of miR-34a mimic (drug: MRX34) used in patients with different types of cancer. Double-stranded miR-34a was encapsulated into a liposome-formulated nanoparticle and administered intravenously [80]. Although, preclinical studies were promising, immune-related serious adverse events (SAEs) appeared during phase I. Due to SAEs this clinical trial was terminated and future phase II trials of MRX34 for melanoma were withdrawn. In contrast human trial of miR-16 mimic (drug: MesomiR-1) exhibited hopeful results in patients with pleural mesothelioma and non-small cell lung cancer. Double-stranded miR-16 was delivered by non-living bacterial minicells with a targeting moiety (i.e., an anti-EGFR bispecific antibody that recognizes EGFR-expressing cancer cells) [81]. This is a new targeted therapy known as TargomiRs. The successful completion of phase I trial confirmed safety and early signs of antitumor activity of TargomiRs so phase II of the trial is expected to begin soon. 
Table 1. Epi-miRs as potential cancer therapeutics.

\begin{tabular}{|c|c|c|c|c|c|c|}
\hline Epi-miRNA & mRNA Target & Cell Lines & Methods & Animal Study & Results & References \\
\hline \multicolumn{7}{|c|}{ Breast cancer } \\
\hline$m i R-34 a$ & $\begin{array}{l}\text { HDAC1 } \\
\text { HDAC7 }\end{array}$ & $\begin{array}{l}\text { MCF-7, MDA-MB-231, BT-20, } \\
\text { T47-D, PC3, DU-145, LNCaP, } \\
\text { NIH:OVCAR, SK-OV-3, HeLa } \\
\text { and non-transformed } \\
\text { mammary MCF-10A cells }\end{array}$ & $\begin{array}{l}\text { miR-34a mimics; luciferase } \\
\text { reporter assay (in MCF-7, PC3, } \\
\text { and MDA-MB-231 cells) }\end{array}$ & ND & $\begin{array}{l}\text { miR-34a expression negatively correlates with } \\
\text { tumor grades; transfection of miR-34a mimic } \\
\text { reduces cell survival and increases the } \\
\text { cytotoxicity of chemotherapy drugs; re-expression } \\
\text { of } m i R-34 a \text { inhibits the tumorigenic activity of } \\
\text { cancer stem cells (CSCs). }\end{array}$ & [82] \\
\hline $\operatorname{miR}-101$ & $E Z H 2$ & SKBR3 & $\begin{array}{l}\text { pre-miR-101; luciferase reporter } \\
\text { assay (in SKBr3 cells) }\end{array}$ & ND & $\begin{array}{l}\text { miR-101 overexpression in } \mathrm{SKBr} 3 \text { attenuates cell } \\
\text { proliferation, migration and inhibits the invasive } \\
\text { potential. }\end{array}$ & [83] \\
\hline $\operatorname{miR}-128$ & BMI1 & SK-3rd, MCF-7 and SKBR3 & $\begin{array}{l}\text { lentivirus vector miR-128; } \\
\text { luciferase reporter assay (in } \\
\text { SK-3rd and MCF-7 cells) }\end{array}$ & ND & $\begin{array}{l}\text { Ectopic expression of miR-128 decreases cell } \\
\text { viability and increases apoptosis and DNA } \\
\text { damage in the presence of doxorubicin; ectopic } \\
\text { miR-128 expression sensitizes BT-ICs (breast } \\
\text { tumor-initiating cells) to doxorubicin enhancing } \\
\text { the DNA damage and pro-apoptotic effects. }\end{array}$ & [84] \\
\hline$m i R-148 a$ & $S M A D 2$ & MDA-MB-231 and Hs-578T & $\begin{array}{l}\text { miR-148a mimics; luciferase } \\
\text { reporter assay (in } \\
\text { MDA-MB-231 cells) }\end{array}$ & $\begin{array}{c}\text { BALB/c nude mice; } \\
\text { MDA-MB-231 cells were } \\
\text { injected s.c.; glabridin (GLA) } \\
\text { was administered } \\
\text { intragastrically each day. }\end{array}$ & $\begin{array}{l}\text { GLA enhances the expression of miR-148a; } \\
\text { GLA-treated tumors have increased expression of } \\
\text { miR-148a and decreased expressions of SMAD2. }\end{array}$ & [75] \\
\hline $\operatorname{miR}-185$ & DNMT1 & $\begin{array}{c}\text { MDA-MB-231, MDA-MB-361, } \\
\text { MDA-MB-435, MDA-MB-468, } \\
\text { MCF-7, T47D, BT-474, BT-20 } \\
\text { and BT-483; normal mammary } \\
\text { epithelial cell lines (HBL-100, } \\
\text { 184A1 and MCF-10A) }\end{array}$ & miR-185 mimics & $\begin{array}{l}\text { Nude mice; MDA-MB- } 231 \text { cells } \\
\text { were injected s.c.; intratumoral } \\
\text { injection of miR-185 mimics. }\end{array}$ & $\begin{array}{l}\text { Ectopic expression of miR-185 inhibits cell } \\
\text { proliferation and induces apoptosis; inhibits } \\
\text { tumor growth in vivo. }\end{array}$ & [85] \\
\hline$m i R 200 b$ & SUZ12 & $\begin{array}{l}\text { MCF-10A cells containing the } \\
\text { ER-Src fusion gene, MCF7, } \\
\text { SKBR3, MDAMB-231, } \\
\text { MDA-MB-435, NSCCs } \\
\text { (non-stem cancer cells) }\end{array}$ & $\begin{array}{l}\text { miR-200b; luciferase reporter } \\
\text { assay (in ER-Src cells) }\end{array}$ & $\begin{array}{l}\text { Athymic nude mice; CSCs } \\
\text { were pretreated with miR-200b } \\
\text { and injected s.c.; ER-Src } \\
\text { (treated and untreated with } \\
\text { tamoxifen) were injected s.c. } \\
\text { and then doxorubicin or } \\
\text { combination doxorubicin and } \\
\text { miR-200b was administered i.p. }\end{array}$ & $\begin{array}{l}\text { miR-200b overexpression affects CSCs growth and } \\
\text { reduces cell invasiveness; pretreatment of CSCs } \\
\text { with } m i R-200 b \text { blocked tumor formation in vivo; } \\
\text { combinatorial therapy (doxorubicin with } \\
\text { miR-200b) causes regression of tumor growth and } \\
\text { prevents relapse of the disease. }\end{array}$ & [72] \\
\hline
\end{tabular}


Table 1. Cont.

\begin{tabular}{|c|c|c|c|c|c|c|}
\hline Epi-miRNA & mRNA Target & Cell Lines & Methods & Animal Study & Results & References \\
\hline \multicolumn{7}{|c|}{ Bladder cancer } \\
\hline miR-101 & EZH2 & T24, UM-UC-3 and TCCSUP & $\begin{array}{l}\text { vector pcDNA3.1 with } \\
\text { pre-miR-101; luciferase reporter } \\
\text { assay (in UM-UC-3 cells) }\end{array}$ & ND & $\begin{array}{l}\text { Restored miR-101 expression inhibits cell } \\
\text { proliferation, suppresses colony formation and } \\
\text { hinders EZH2-mediated neoplastic progression. }\end{array}$ & [86] \\
\hline$m i R-124$ & UHRF1 & $\begin{array}{l}\text { J82, T24, HEK } 293 \text { and } \\
\text { SV-HUC-1 }\end{array}$ & $\begin{array}{l}\text { miR-124 mimics; luciferase } \\
\text { reporter assay (in } \\
\text { HEK-293cells) }\end{array}$ & $\begin{array}{l}\text { Male BALB/C-A mice; T24 cells } \\
\text { were injected s.c. and then } \\
\text { intratumoral injection was } \\
\text { performed with miR-124 } \\
\text { mimics. }\end{array}$ & $\begin{array}{l}\text { miR-124 overexpression attenuates cell } \\
\text { proliferation, migration, invasion and } \\
\text { vasculogenic mimicry; inhibits tumor growth } \\
\text { in vivo. }\end{array}$ & [87] \\
\hline$m i R-144$ & EZH2 & $\mathrm{T} 24$ & $\begin{array}{c}\text { vector pcDNA-miR-144; } \\
\text { luciferase reporter assay (in } \\
\text { HEK293 cells) }\end{array}$ & ND & $\begin{array}{l}\text { miR-144 overexpression inhibits cell proliferation; } \\
\text { decreases EZH2 protein levels. }\end{array}$ & [88] \\
\hline $\begin{array}{l}\text { miR-145-5p } \\
\text { miR-145-3p }\end{array}$ & UHRF1 & T24 and BOY & $\begin{array}{l}\text { pre-miR-145-5p and } \\
\text { pre-miR-145-3p; luciferase } \\
\text { reporter assay (in T24 and BOY } \\
\text { cells) }\end{array}$ & ND & $\begin{array}{l}\text { Ectopic expression of either } m i R-145-5 p \text { or } \\
\text { miR-145-3p suppresses cancer cell growth, } \\
\text { migration and invasion and induces apoptosis. }\end{array}$ & [89] \\
\hline$m i R-148 a$ & DNMT1 & $\begin{array}{l}\text { SV-HUC-1, T24, TCCSUP, J82 } \\
\text { and UM-UC-3 }\end{array}$ & $\begin{array}{l}\text { miR-148a mimics; cisplatin or } \\
\text { doxorubicin treatment }\end{array}$ & ND & $\begin{array}{l}\text { miR-148a overexpression reduces cell viability by } \\
\text { promoting apoptosis; combinatorial therapy } \\
\text { (miR-148a/cisplatin or } m i R-148 a / \text { doxorubicin }) \\
\text { enhanced apoptosis. }\end{array}$ & [71] \\
\hline \multicolumn{7}{|c|}{ Colorectal cancer } \\
\hline$m i R-9$ & UHRF1 & HCT116 and HT29 & $\begin{array}{l}\text { miR-9 oligonucleotides; } \\
\text { lentivirus vector } m i R-9 ; \\
\text { luciferase reporter assay (in } \\
\text { HCT116 and HT29 cells) }\end{array}$ & ND & $\begin{array}{l}\text { miR-9 overexpression attenuates CRC cell } \\
\text { proliferation and promotes cell apoptosis; reduces } \\
\text { UHRF1 expression. }\end{array}$ & [90] \\
\hline$m i R-143$ & DNMT3A & $\begin{array}{l}\text { 228, CaCO2, Clone A, HCT116, } \\
\text { HT-29, MIP101 and SW480 }\end{array}$ & $\begin{array}{l}\text { pre-miR-143; luciferase reporter } \\
\text { assay (in } 228 \text { and SW } 480 \text { cells) }\end{array}$ & ND & $\begin{array}{l}\text { Ectopic expression of miR-143 inhibits cell growth, } \\
\text { reduces clone formation; restored miR-143 } \\
\text { expression decreases tumor cell growth and } \\
\text { soft-agar colony formation, and downregulates } \\
\text { DNMT3A expression. } \\
\end{array}$ & [91] \\
\hline $\operatorname{miR}-342$ & DNMT1 & $\begin{array}{l}\text { SW480, HT29, HCT116 and } \\
\text { HEK293T }\end{array}$ & $\begin{array}{l}\text { miR-342 oligonucleotides; } \\
\text { lentivirus vector } m i R-342 ; \\
\text { luciferase reporter assay (in } \\
\text { SW480 cells) }\end{array}$ & $\begin{array}{l}\text { Female athymic BABL/c nude } \\
\text { mice; cell lines stably } \\
\text { expressing miR-342 were } \\
\text { injected s.c. }\end{array}$ & $\begin{array}{c}\text { Enhanced miR-342 expression inhibits cell } \\
\text { proliferation and invasion; miR-342 } \\
\text { overexpression leads to demethylation and } \\
\text { induction of tumor suppressor genes through } \\
\text { blocking DNMT1 expression; } m i R-342 \\
\text { overexpression inhibits tumor growth and lung } \\
\text { metastasis in vivo. }\end{array}$ & [92] \\
\hline
\end{tabular}


Table 1. Cont.

\begin{tabular}{|c|c|c|c|c|c|c|}
\hline Epi-miRNA & mRNA Target & Cell Lines & Methods & Animal Study & Results & References \\
\hline \multicolumn{7}{|c|}{ Endometrial cancer } \\
\hline miR-101 & EZH2 & $\begin{array}{l}\text { SPAC-1-L and SPAC-1-S; } \\
\text { HEC-50 and HOUA-I cell lines } \\
\text { were derived from } \\
\text { poorly-differentiated } \\
\text { endometrioid EC (endometrial } \\
\text { carcinoma) }\end{array}$ & $\begin{array}{l}\text { vector with pre-miR-101-3p; } \\
\text { luciferase reporter assay (in } \\
\text { SPAC-1-L and HOUA-I cells) }\end{array}$ & ND & $\begin{array}{l}\text { Ectopic overexpression of } m i R-101 \text { suppresses cell } \\
\text { proliferation, attenuates the } \\
\text { epithelial-mesenchymal transition associated } \\
\text { cancer cell migration and invasion, abrogates the } \\
\text { sphere-forming capacity and enhances } \\
\text { chemosensitivity to paclitaxel. }\end{array}$ & [93] \\
\hline \multicolumn{7}{|c|}{ Esophageal cancer } \\
\hline $\operatorname{miR}-203$ & BMI1 & EC9706 and KYSE150 & $\begin{array}{l}\text { lentivirus vector } m i R-203 \text {; } \\
\text { luciferase reporter assay (in } \\
\text { EC9706 cells) }\end{array}$ & $\begin{array}{c}\text { Female nude mice and } \\
\text { nonobese diabetic/severe } \\
\text { combined immunodeficient } \\
\text { mice; freshly prepared cells } \\
\text { were injected s.c. }\end{array}$ & $\begin{array}{l}\text { miR-203 overexpression reduces colony formation, } \\
\text { tumorigenicity ability and self-renewal of } \\
\text { esophageal cancer stem-like cells; increases } \\
\text { sensitivity to cisplatin. }\end{array}$ & [94] \\
\hline \multicolumn{7}{|c|}{ Gastric cancer } \\
\hline$m i R-29 b / c$ & DNMT3A & AGS and BGC-823 & $\begin{array}{l}\text { miR-29b/c mimics; luciferase } \\
\text { reporter assay (in BGC-823 } \\
\text { cells) }\end{array}$ & ND & $\begin{array}{l}\text { miR-29b/c overexpression decreases migration and } \\
\text { reduces invasive ability; miR-29b/c suppresses the } \\
\text { expression of DNMT3A. }\end{array}$ & [95] \\
\hline $\begin{array}{l}m i R-146 a \\
m i R-146 b\end{array}$ & UHRF1 & $\begin{array}{c}\text { GC9811, GC9811-P, } \\
\text { MKN28NM and MKN28M }\end{array}$ & $\begin{array}{l}\text { pre-miR-146a/b; lentivirus } \\
\text { vector } m i R-146 a / b ; \text { luciferase } \\
\text { reporter assay (in HEK293T } \\
\text { and GC9811 cells) }\end{array}$ & $\begin{array}{l}\text { Nude mice; metastasis assay: } \\
\text { GC9811-P cells infected with } \\
\text { miR-146a/b were injected into } \\
\text { the tail vein. }\end{array}$ & $\begin{array}{l}\text { Restored expression of miR-146a/b reduces the } \\
\text { expression of UHRF1; upregulation of } m i R-146 a / b \\
\text { suppresses metastasis. }\end{array}$ & [96] \\
\hline miR-148a & DNMT1 & $\begin{array}{l}\text { SGC-7901, BGC-823 and GES-1 } \\
\text { (human gastric } \\
\text { epithelium-immortalized cell } \\
\text { line) }\end{array}$ & $m i R-148 a$ mimics & ND & $\begin{array}{l}\text { miR-148a mimics suppresses cell proliferation; } \\
\text { miR-148a overexpression decreases DNMT1 } \\
\text { expression and induces the overexpression of } \\
\text { MEG3 (lncRNA). }\end{array}$ & [97] \\
\hline$m i R-206$ & $H D A C 4$ & $\begin{array}{l}\text { SGC-7901, BGC-823, AGS, } \\
\text { non-malignant gastric cell line } \\
\text { GES-1 and HEK293T }\end{array}$ & $\begin{array}{l}\text { miR-206 mimics; vector with } \\
\text { miR-206 }\end{array}$ & $\begin{array}{l}\text { Nude mice; SGC-7901 cells } \\
\text { carrying P2GM-miR-206 was } \\
\text { injected s.c. }\end{array}$ & $\begin{array}{l}\text { Ectopic expression of miR-206 represses cell } \\
\text { proliferation, colony formation, invasion and } \\
\text { migration; } m i R-206 \text { promotes myogenic } \\
\text { differentiation and blocks tumor growth in vivo. }\end{array}$ & [98] \\
\hline \multicolumn{7}{|c|}{ Glioblastoma } \\
\hline$m i R-128$ & Bim-1 & $\begin{array}{l}\text { U87MG, U251MG and } \\
\text { U373MG }\end{array}$ & $\begin{array}{l}\text { pre-miR-128 mimics; lentivirus } \\
\text { vector } \text { pri-miR-128-1; luciferase } \\
\text { reporter assay (in U87, U251, } \\
\text { and U373 cells) }\end{array}$ & $\begin{array}{l}\text { Athymic mice; U87 cells stably } \\
\text { expressing miR-128 were } \\
\text { implanted s.c. }\end{array}$ & $\begin{array}{l}\text { miR-128 expression reduces glioma cell } \\
\text { proliferation, self-renewal in vitro and glioma } \\
\text { xenograft growth in vivo. }\end{array}$ & [99] \\
\hline $\operatorname{miR}-128$ & $\begin{array}{l}\text { SUZ12 } \\
\text { BMI1 }\end{array}$ & $\begin{array}{l}\text { U87 malignant glioma (MG) } \\
\text { and U251MG glioblastoma } \\
\text { cells }\end{array}$ & $\begin{array}{l}\text { pre-miR-128; lentivirus vector } \\
\text { miR-128; luciferase reporter } \\
\text { assay (in HEK293 cells) }\end{array}$ & $\begin{array}{l}\text { Mut3 mice (hGFAP-cre; } \\
\text { Nf1flox/+; Trp532/+). }\end{array}$ & $\begin{array}{l}\text { miR-128 overexpression reduces proliferative } \\
\text { potential and colony formation; reestablishment } \\
\text { of miR-128 expression impairs glioma stem-like } \\
\text { cells self-renewal and increases their } \\
\text { radiosensitivity. }\end{array}$ & [100] \\
\hline
\end{tabular}


Table 1. Cont.

\begin{tabular}{|c|c|c|c|c|c|c|}
\hline Epi-miRNA & mRNA Target & Cell Lines & Methods & Animal Study & Results & References \\
\hline \multicolumn{7}{|c|}{ Head and neck squamous cell carcinoma } \\
\hline$m i R-874$ & $H D A C 1$ & $\begin{array}{l}\text { SAS, FaDu, HSC3, IMC-3, } \\
\text { human fibroblast and MRC-5 }\end{array}$ & $\begin{array}{l}\text { mature miR-874; luciferase } \\
\text { reporter assay (in SAS cells) }\end{array}$ & ND & $\begin{array}{l}\text { Restoration of } m i R-874 \text { inhibits cell proliferation, } \\
\text { induces cell cycle arrest and apoptosis. }\end{array}$ & [101] \\
\hline \multicolumn{7}{|c|}{ Hepatobiliary cancer } \\
\hline $\begin{array}{l}\text { miR-152 } \\
\text { miR-148a }\end{array}$ & DNMT1 & $\begin{array}{l}\text { KMCH-1, Mz-ChA-1, TFK-1 } \\
\text { and H69; Mz-IL-6 (KMCH-1 } \\
\text { stably transfected with IL-6) }\end{array}$ & $\begin{array}{l}\text { pre-miR-152 and pre-miR-148a; } \\
\text { luciferase reporter assay (in } \\
\text { Mz-ChA-1 cells) }\end{array}$ & $\begin{array}{l}\text { Male athymic nu/nu mice; } \\
\text { Mz-IL-6 cells were injected s.c. }\end{array}$ & $\begin{array}{l}\text { pre-miR-148a and pre-miR-152 decreases DNMT-1 } \\
\text { protein expression and reduces cell proliferation; } \\
\text { miR-148a and miR-152 expression was reduced in } \\
\text { tumor cell xenografts in vivo. }\end{array}$ & [102] \\
\hline \multicolumn{7}{|c|}{ Hepatocellular carcinoma } \\
\hline miR-22 & HDAC4 & Hep3B and SMMC7721 & $\begin{array}{l}m i R-22 \text { mimics; luciferase } \\
\text { reporter assay (in Hep3B cells) }\end{array}$ & $\begin{array}{l}\text { Male BALB/c athymic nude } \\
\text { mice; } m i R-22 \text { mimics } \\
\text { transfected Hep3B or } \\
\text { SMMC7721 cells were injected } \\
\text { s.c. }\end{array}$ & $\begin{array}{l}\text { Restoration of } m i R-22 \text { expression suppresses cell } \\
\text { proliferation and endogenous expression of } \\
\text { HDAC4 protein; } m i R-22 \text { transfection delays tumor } \\
\text { formation and reduces tumor size in vivo. }\end{array}$ & [103] \\
\hline $\begin{array}{l}\operatorname{miR}-29 a \\
\operatorname{miR}-185\end{array}$ & $\begin{array}{l}\text { DNMT3A } \\
\text { DNMT3B }\end{array}$ & HepG2 and HuH-7 & $\begin{array}{l}\text { dendrosomal curcumin (DNC) } \\
\text { treatment }\end{array}$ & ND & $\begin{array}{l}\text { Overexpression of } m i R-29 a \text { and } m i R-185 \text { after } \\
\text { dendrosomal curcumin (DNC) treatment, } \\
\text { down-regulates the expression of DNMT1, 3A } \\
\text { and 3B. }\end{array}$ & [74] \\
\hline $\operatorname{miR}-145$ & $H D A C 2$ & $\begin{array}{l}\text { Hep3B, HepG2, SNU-182, } \\
\text { SNU-449 and PLC/PRF/5 }\end{array}$ & $\begin{array}{l}\text { miR-145 mimics; vector with } \\
\text { miR-145; luciferase reporter } \\
\text { assay (in SNU-449 cells) }\end{array}$ & $\begin{array}{l}\text { Male athymic nude mice; } \\
\text { Hep3B cells transfected with } \\
\text { miR-145 were injected s.c. }\end{array}$ & $\begin{array}{l}\text { Ectopic expression of miR-145 inhibits cell growth } \\
\text { and HDAC2 expression; inhibits tumor growth } \\
\text { in vivo. }\end{array}$ & [104] \\
\hline$m i R-200 a$ & $H D A C 4$ & SMMC-7721 and HepG2 & $\begin{array}{l}\text { miR-200a mimics; lentivirus } \\
\text { vector } m i R-200 a ; \text { luciferase } \\
\text { reporter assay (in SMMC-7721 } \\
\text { cells) }\end{array}$ & $\begin{array}{l}\text { Nude mice; HepG2 cells stably } \\
\text { transfected with miR-200a were } \\
\text { implanted s.c. }\end{array}$ & $\begin{array}{l}\text { miR-200a inhibits cell proliferation and migration } \\
\text { both in vivo and in vitro; miR-200a } \\
\text { overexpression induces up-regulation of global } \\
\text { acetyl-histone H3. }\end{array}$ & [105] \\
\hline \multicolumn{7}{|c|}{ Acute myeloid leukemia } \\
\hline$m i R-29 b$ & $\begin{array}{l}\text { DNMT3A } \\
\text { DNMT3B }\end{array}$ & $\begin{array}{l}\text { AML cell lines, Kasumi- } 1 \text {, } \\
\text { MV4-11 and K562 }\end{array}$ & $\begin{array}{l}\text { pre-miR-29b; lentivirus vector } \\
\text { miR-29b; luciferase reporter } \\
\text { assays (in K562 cells) }\end{array}$ & ND & $\begin{array}{l}\text { Enforced expression of miR-29b in AML cells } \\
\text { reduces of the expression of DNMT1, DNMT3A, } \\
\text { and DNMT3B; pre-miR-29b overexpression } \\
\text { induces partial differentiation of AML blasts. }\end{array}$ & [79] \\
\hline$m i R-29 b$ & DNMT3B & $\begin{array}{l}\text { primary AML blasts, K562 and } \\
\text { Kasumi-1 }\end{array}$ & synthetic miR-29b & $\begin{array}{l}\text { Female nude mice; synthetic } \\
\text { miR-29b oligonucleotides were } \\
\text { injected directly into the } \\
\text { tumors. }\end{array}$ & $\begin{array}{l}\text { Restoring miR-29b expression, induces apoptosis } \\
\text { and dampens cell growth in AML cells. }\end{array}$ & [106] \\
\hline miR-193a-3p & $\begin{array}{l}\text { DNMT3A } \\
\text { HDAC3 }\end{array}$ & $\begin{array}{l}\text { HL60, U937, U937-A/E-HA, } \\
\text { Kasumi-1, SKNO-1, } \\
\text { SKNO-1-siA/E-RNA and KG1 }\end{array}$ & $\begin{array}{l}\text { miR-193a mimics; lentivirus } \\
\text { vector miR-193a; luciferase } \\
\text { reporter assay (in 293T cells) }\end{array}$ & $\begin{array}{l}\text { Nude mice; SKNO-1 cells were } \\
\text { injected s.c.; intratumor } \\
\text { injection of miR-193a. }\end{array}$ & $\begin{array}{l}\text { Enhanced miR-193a levels induce G1 arrest, } \\
\text { apoptosis, and restores leukemic cell } \\
\text { differentiation; decreases tumor size in vivo. }\end{array}$ & [107] \\
\hline
\end{tabular}


Table 1. Cont.

\begin{tabular}{|c|c|c|c|c|c|c|}
\hline Epi-miRNA & mRNA Target & Cell Lines & Methods & Animal Study & Results & References \\
\hline \multicolumn{7}{|c|}{ Chronic myeloid leukemia } \\
\hline$m i R-217$ & DNMT3A & Bcr/Abl-expressing K562 cells & $\begin{array}{l}\text { lentivirus vector } m i R-217 \text {; } \\
\text { luciferase reporter assay (in } \\
\text { K562DR cells) }\end{array}$ & $\begin{array}{l}\text { Female immune deficient } \\
\text { BALB/c nude mice; K562 cells } \\
\text { were injected s.c.; drug } \\
\text { administration: dasatinib or } \\
\text { 5-AzadC or a combination of } \\
\text { both dasatinib and 5-AzadC. }\end{array}$ & $\begin{array}{l}\text { Forced expression of miR-217 inhibits expression } \\
\text { of DNMT3A and sensitizes cells to growth } \\
\text { inhibition mediated by the tyrosine kinase } \\
\text { inhibitors (prevents drug resistance). }\end{array}$ & [108] \\
\hline \multicolumn{7}{|c|}{ Multiple myeloma } \\
\hline $\operatorname{miR}-29 b$ & $\begin{array}{l}\text { DNMT3A } \\
\text { DNMT3B }\end{array}$ & MM cell lines & $\begin{array}{c}\text { pre-miR-29b mimics } \\
\text { (formulated with a Neutral } \\
\text { Lipid Emulsion (NLE) delivery } \\
\text { system); lentivirus vector } \\
\text { miR-29b; luciferase reporter } \\
\text { assay (in INA-6 cells) }\end{array}$ & $\begin{array}{l}\text { Male CB-17 severe combined } \\
\text { immunodeficient (SCID) mice; } \\
\text { MM cells were inoculated s.c.; } \\
\text { miR-29b mimics were } \\
\text { administered intratumorally } \\
\text { and systemically via tail vein. }\end{array}$ & $\begin{array}{l}\text { miR-29b mimics impair cell cycle progression and } \\
\text { potentiate the growth-inhibitory effects induced } \\
\text { by the demethylating agent } 5 \text {-azacitidine; miR-29b } \\
\text { mimics induce anti-tumor effects in vivo. }\end{array}$ & {$[70]$} \\
\hline \multicolumn{7}{|c|}{ Leukemia } \\
\hline $\operatorname{miR}-143$ & DNMT3A & $\begin{array}{l}\text { AML (HL-60, NB4 and U937), } \\
\text { CML (K562), acute } \\
\text { erythroleukemia (HEL), T } \\
\text { lymphocytic leukemia (Jurkat } \\
\text { and CEM), B-cell lymphoma } \\
\text { (CA46, Raji cells of Burkitt's } \\
\text { lymphoma) and multiple } \\
\text { myeloma (U266) }\end{array}$ & lentivirus vector $m i R-143$ & ND & $\begin{array}{l}\text { miR-143 overexpression decreases DNMT3A } \\
\text { mRNA and protein expression, reduces cell } \\
\text { proliferation, colony formation and cell cycle } \\
\text { progression as well as induces apoptosis. }\end{array}$ & [109] \\
\hline \multicolumn{7}{|c|}{ Lung cancer } \\
\hline$m i R-29 a,-b,-c$ & $\begin{array}{l}\text { DNMT3A } \\
\text { DNMT3B }\end{array}$ & A549 and H1299 & $\begin{array}{l}\text { pre-miR-29a, }-29 b-1,-29 c \\
\text { oligonucleotides; luciferase } \\
\text { reporter assay (in A549 cells) }\end{array}$ & $\begin{array}{l}\text { Female nude mice; A549 cells } \\
\text { transfected with pre- } m i R-29 a \\
-29 b \text {, or }-29 c \text {, were injected s.c. }\end{array}$ & $\begin{array}{c}\text { Enforced expression of miR-29s restores normal } \\
\text { patterns of DNA methylation, induces } \\
\text { re-expression of methylation-silenced tumor } \\
\text { suppressor genes and inhibits tumorigenicity } \\
\text { in vitro and in vivo. }\end{array}$ & {$[68]$} \\
\hline $\begin{array}{l}\text { miR-193a-3p } \\
\text { miR-193a-5p }\end{array}$ & UHRF1 & $\begin{array}{c}\text { SPC-A-1, SPC-A-1sci, A549, } \\
\text { H1299, LC-21, H358 and } \\
\text { HEK-293T }\end{array}$ & $\begin{array}{l}\text { miR-193a-3p/5p mimics; } \\
\text { lentivirus vector } \\
\text { miR-193a-3p/5p; luciferase } \\
\text { reporter assay (in HEK293T } \\
\text { cells) }\end{array}$ & $\begin{array}{l}\text { BALB/C-nu/nu nude male mice; } \\
\text { metastasis assays: SPC-A-1sci } \\
\text { cells stably expressing the } \\
\text { miR-193a-3p/5p-mimic were } \\
\text { injected into the tail vein. }\end{array}$ & $\begin{array}{l}\text { miR-193a-3p/5p overexpression inhibits cell } \\
\text { proliferation, migration, invasion and } \\
\text { epithelial-mesenchymal transition (EMT); lung } \\
\text { metastasis formation in vivo. }\end{array}$ & [110] \\
\hline \multicolumn{7}{|c|}{ Lymphoma } \\
\hline$m i R-26 a$ & EZH2 & $\begin{array}{l}\text { human BL cell lines; murine } \\
\text { MYC-induced lymphoma cell } \\
\text { lines }\end{array}$ & $\begin{array}{c}\text { vectors with mature } m i R-26 a \\
\text { luciferase reporter assay (in } \\
\text { HEK-293 cells) }\end{array}$ & ND & $\begin{array}{l}m i R-26 a \text { overexpression reduces cell numbers and } \\
\text { results in an anti-proliferative effect. }\end{array}$ & [111] \\
\hline
\end{tabular}


Table 1. Cont.

\begin{tabular}{|c|c|c|c|c|c|c|}
\hline Epi-miRNA & mRNA Target & Cell Lines & Methods & Animal Study & Results & References \\
\hline \multicolumn{7}{|c|}{ Melanoma } \\
\hline$m i R-200 c$ & BMI1 & $\begin{array}{l}\text { WM35, WM793, WM115A, } \\
\text { M3523A, 1205Lu and 293T }\end{array}$ & $\begin{array}{l}\text { lentivirus vector } m i R-200 c \text {; } \\
\text { vector pEZX-miR-200c }\end{array}$ & $\begin{array}{l}\text { Male athymic nu/nu mice; } \\
\text { miR-200c-WM115A cells were } \\
\text { injected s.c. }\end{array}$ & $\begin{array}{l}\text { miR-200c overexpression decreases cell } \\
\text { proliferation, colony formation and migratory } \\
\text { capacity as well as drug resistance and increases } \\
\text { sensitivity to various chemotherapeutic agents } \\
\text { (including cisplatin); inhibits melanoma xenograft } \\
\text { growth and metastasis in vivo. }\end{array}$ & [112] \\
\hline \multicolumn{7}{|c|}{ Neuroblastoma } \\
\hline $\operatorname{miR}-137$ & EZH2 & $\begin{array}{l}\text { Mouse Neuro-2a (N-2a); } \\
\text { human SH-SY5Y }\end{array}$ & $\begin{array}{l}\text { miR-137 mimics; resveratrol } \\
\text { (RSV) treatment; luciferase } \\
\text { reporter assay (in HEK293 } \\
\text { cells) }\end{array}$ & ND & $\begin{array}{l}\text { miR-137 expression is up-regulated after RSV } \\
\text { treatment; miR-137 inhibits EZH2 expression after } \\
\text { RSV treatment; miR-137 regulates the } \\
\text { EZH2-mediated apoptosis after RSV treatment. }\end{array}$ & [73] \\
\hline$m i R-124$ & $E Z H 2$ & $\begin{array}{c}\text { Neural Stem Cells (NSCs) and } \\
\text { HEK293T }\end{array}$ & mature $m i R-124$ & ND & $\begin{array}{l}\text { miR-124 overexpression down-regulates } \\
\text { expression of Ezh2 and up-regulates } \\
\text { neuron-specific Ezh2 target genes; promotes } \\
\text { neuronal differentiation. }\end{array}$ & [113] \\
\hline$m i R-137$ & KDM1A & $\begin{array}{l}\text { IMR-32, SHEP, SKN-BE and } \\
\text { HEK-293 }\end{array}$ & $\begin{array}{c}\text { pre-miR-137; luciferase reporter } \\
\text { assay (in SHEP and HEK293 } \\
\text { cells) }\end{array}$ & ND & $\begin{array}{l}\text { Re-expression of miR-137 increases apoptosis, } \\
\text { decreases cell viability and proliferation, induces } \\
\text { neuronal differentiation; downregulates KDM1A. }\end{array}$ & [114] \\
\hline$m i R-152$ & DNMT1 & $\begin{array}{l}\text { SK-N-BE, SH-SY5Y, SK-N-AS } \\
\text { and Kelly }\end{array}$ & $\begin{array}{l}\text { pre-miR-152; luciferase reporter } \\
\text { assay (in Kelly cells) }\end{array}$ & ND & $\begin{array}{l}\text { Ectopic upregulation of miR-152 declines cell } \\
\text { invasiveness and anchorage-independent cell } \\
\text { growth, contributing to the differentiated } \\
\text { phenotype. }\end{array}$ & [115] \\
\hline \multicolumn{7}{|c|}{ Oral squamous cell carcinoma } \\
\hline$m i R-32$ & EZH2 & $\begin{array}{l}\text { SCC-4, SCC-9, SCC-25 and } \\
\text { Tca8113; normal oral } \\
\text { keratinocyte cell line (hNOK) }\end{array}$ & $\begin{array}{c}\text { mature miR-32 mimics; } \\
\text { luciferase reporter assay (in } \\
\text { Tca8113 cells) }\end{array}$ & ND & $\begin{array}{l}\text { miR-32 overexpression reduces cell proliferation, } \\
\text { migration and invasion, promotes cell apoptosis; } \\
\text { miR-32 down-regulates the expression of EZH2. }\end{array}$ & [116] \\
\hline \multicolumn{7}{|c|}{ Ovarian cancer } \\
\hline $\begin{array}{l}\operatorname{miR}-15 a \\
\operatorname{miR}-16\end{array}$ & BMI1 & $\begin{array}{c}\text { OVCAR-5, OV-167, OV-202, } \\
\text { CP-70, A2780 and OSE } \\
\text { (ovarian surface epithelial cell) }\end{array}$ & $\begin{array}{l}\text { pre-miR-15a, pre-miR-16; } \\
\text { luciferase reporter assay (in } \\
\text { OV-202 and CP-70 cells) }\end{array}$ & ND & $\begin{array}{c}\text { miR-15a or miR-16 overexpression decreases cell } \\
\text { proliferation and clonal growth; downregulates } \\
\text { BMI1 protein levels. }\end{array}$ & [117] \\
\hline $\begin{array}{l}\text { miR-152 } \\
\text { miR-185 }\end{array}$ & DNMT1 & $\begin{array}{c}\text { SKOV3, A2780, A2780/DDP } \\
\text { (cisplatin-resistant), A549 and } \\
\text { HepG2 }\end{array}$ & $\begin{array}{l}\text { miR-152 and miR-185 mimics; } \\
\text { luciferase reporter assay (in } \\
\text { SKOV3/DDP cells) }\end{array}$ & $\begin{array}{l}\text { CD-1/CD-1 nude mice; } \\
\text { SKOV3/DDP cells transfected } \\
\text { with miR-152 that were } \\
\text { injected i.p. }\end{array}$ & $\begin{array}{l}\text { miR-152 or miR-185 overexpression increases } \\
\text { cisplatin sensitivity by inhibiting proliferation } \\
\text { and promoting apoptosis; promotes sensitivity to } \\
\text { cisplatin through targeting DNMT1 directly. }\end{array}$ & [118] \\
\hline \multicolumn{7}{|c|}{ Pancreatic cancer } \\
\hline $\begin{array}{l}\operatorname{miR}-148 a \\
\operatorname{miR} 152\end{array}$ & DNMT1 & MIA PaCa-2 and AsPC- 1 & $\begin{array}{l}\text { pre-miR-148b, pre-miR-152; } \\
\text { luciferase reporter assay (in } \\
\text { MIA PaCa-2 and AsPC-1 cells) }\end{array}$ & ND & $\begin{array}{l}\text { miR-148b and miR-152 overexpression inhibits cell } \\
\text { proliferation and induces apoptosis; decreases } \\
\text { DNMT1 expression, returns DNA methylation to } \\
\text { normal patterns and induces re-expression of } \\
\text { tumor suppressor genes. }\end{array}$ & [119] \\
\hline
\end{tabular}


Table 1. Cont.

\begin{tabular}{|c|c|c|c|c|c|c|}
\hline Epi-miRNA & mRNA Target & Cell Lines & Methods & Animal Study & Results & References \\
\hline \multicolumn{7}{|c|}{ Prostate cancer } \\
\hline miR-101 & EZH2 & DU145 & $\begin{array}{l}\text { pre-miR-101; luciferase reporter } \\
\text { assay (in SKBr3 cells) }\end{array}$ & $\begin{array}{l}\text { Male nude athymic BALB/c } \\
\text { nu/nu mice, DU145 stable cells } \\
\text { overexpressing miR-101 were } \\
\text { injected s.c. }\end{array}$ & $\begin{array}{l}\text { miR-101 overexpression attenuates cell } \\
\text { proliferation, migration and invasive potential; } \\
\text { reduces colony formation; reduces tumor growth } \\
\text { in vivo. }\end{array}$ & [83] \\
\hline$m i R-145$ & DNMT3B & PC3 & $\begin{array}{l}\text { miR-145 mimics; luciferase } \\
\text { reporter assay (in PC3 cells) }\end{array}$ & ND & $\begin{array}{l}\text { miR-145 overexpression downregulates the } \\
\text { expression of DNMT3B; sensitizes prostate cancer } \\
\text { cells to X-ray radiation. }\end{array}$ & [120] \\
\hline$m i R-449 a$ & $H D A C 1$ & $\begin{array}{c}\text { PC-3, DU-145, BPH-1 and } \\
\text { LNCaP }\end{array}$ & $\begin{array}{l}\text { mature } m i R-449 a \text { mimics; a } \\
\text { longer, dicer-dependent } \\
\text { pre-miR-449a; luciferase } \\
\text { reporter assays (in PC-3 cells) }\end{array}$ & ND & $\begin{array}{l}\text { miR-449 expression arrests cell cycle, apoptosis; } \\
\text { regulates cell growth and viability in part by } \\
\text { repressing the expression of HDAC-1. }\end{array}$ & [121] \\
\hline \multicolumn{7}{|c|}{ Renal cell carcinoma } \\
\hline miR-101 & UHRF1 & 786-O and Caki-1 & $\begin{array}{l}\text { pre-miR-101-3p; luciferase } \\
\text { reporter assay (in 786-O cells) }\end{array}$ & $\mathrm{ND}$ & $\begin{array}{l}\text { Restoration of miR-101 inhibits cell proliferation, } \\
\text { migration and decreases invasion activity; } \\
\text { suppresses UHRF1 expression. }\end{array}$ & [122] \\
\hline \multicolumn{7}{|c|}{ Rhabdomyosarcoma } \\
\hline$m i R-29$ & Yin Yang $1(Y Y 1)$ & $\begin{array}{c}\mathrm{C} 2 \mathrm{C} 12 \text { myoblasts, } \mathrm{RH} 30 \text { and } \\
\text { RD2 }\end{array}$ & $\begin{array}{l}\text { pre-miR-29; lentivirus vector } \\
\text { miR-29; luciferase reporter } \\
\text { assays (in MB cells) }\end{array}$ & $\begin{array}{l}\text { Athymic nu/nu female mice; } \\
\text { RH30 cells were injected s.c.; } \\
\text { intratumoral injection of } \\
\text { lentivirus with miR-29. }\end{array}$ & $\begin{array}{l}\text { miR-29 overexpression reduces cell growth and } \\
\text { increases levels of the differentiation markers; } \\
\text { intratumoral addition of } m i R-29 \text { stimulates } \\
\text { myogenic differentiation; inhibits tumor growth } \\
\text { in vivo. }\end{array}$ & [123] \\
\hline \multicolumn{7}{|c|}{ Testicular cancer } \\
\hline miR-199a-3p & $\begin{array}{c}\text { DNMT3A } \\
\text { (especially } \\
\text { DNMT3A2) }\end{array}$ & Ntera 2 (NT2) & $\begin{array}{l}\text { miR-199a-3p mimics; luciferase } \\
\text { reporter assay (in NT2 cells) }\end{array}$ & ND & $\begin{array}{l}\text { miR-199a-3p overexpression restores the } \\
\text { expression of tumor-suppressor genes by affecting } \\
\text { DNA methylation of their promoter regions. }\end{array}$ & [124] \\
\hline \multicolumn{7}{|c|}{ Waldenström macroglobulinemia } \\
\hline miRNA-9* & $\begin{array}{l}\text { HDAC4 } \\
\text { HDAC5 }\end{array}$ & $\begin{array}{l}\text { BCWM.1, WM-WSU, MEC-1 } \\
\text { and RL }\end{array}$ & pre-miRNA-9 * & ND & $\begin{array}{l}\text { Restoring miRNA- } 9 * \text { levels induces toxicity, } \\
\text { apoptosis and autophagy; supports } \\
\text { down-modulation of HDAC4 and HDAC5 and } \\
\text { up-regulation of acetyl-histone-H3 and -H4 }\end{array}$ & [125] \\
\hline
\end{tabular}

ND—no data; s.c.—subcutaneous; i.p.—intraperitoneal injection. * miR-9-3p. 


\section{Conclusions}

Knowledge in the miRNA field is steadily increasing and recent information about the mechanisms of action, especially their involvement in epigenetic regulation has shed new light on cellular regulatory networks.

Interestingly, mature miRNAs are present in both the nucleus and the cytoplasm, therefore they can be involved in the regulation of transcription and translation processes. Nuclear miRNAs can influence gene expression via transcriptional activation or transcriptional gene silencing and shaping alternative splicing, Cytoplasmic miRNAs mainly mediated translation inhibition, however, some miRNAs are capable of activating translation of their target mRNA. A growing body of evidence suggests that miRNAs can act as regulators of the cell epigenome through translation inhibition of proteins engaged in epigenetic control and/or interaction with lncRNA. Considering the pervasive role of miRNAs in numerous biological processes, especially tumorigenesis, better understanding of their role in epigenetic regulation will aid the development of new therapeutic strategies.

Currently, miRNA-based treatment approaches for cancer, including tumor-suppressor epi-miRs, are tested in in vitro and in vivo experiments. Although results seem promising further studies will be needed to clarify the safety and effectiveness of epi-miR therapy in clinical practice. We strongly believe that re-introduction of tumor-suppressor epi-miRs will allow for more effective, personalized therapies in the near future.

Funding: No external funding was used in the preparation of this article.

Acknowledgments: The author thanks Monika Chojnacka for assistance in language and text editing.

Conflicts of Interest: The author declares no conflict of interest.

\section{References}

1. Lemcke, H.; David, R. Potential mechanisms of microRNA mobility. Traffic 2018, 19, 910-917. [CrossRef] [PubMed]

2. Garcia-Lopez, J.; Brieno-Enriquez, M.A.; Del Mazo, J. MicroRNA biogenesis and variability. Biomol. Concepts 2013, 4, 367-380. [CrossRef] [PubMed]

3. Jo, M.H.; Shin, S.; Jung, S.R.; Kim, E.; Song, J.J.; Hohng, S. Human Argonaute 2 Has Diverse Reaction Pathways on Target RNAs. Mol. Cell 2015, 59, 117-124. [CrossRef] [PubMed]

4. O'Brien, J.; Hayder, H.; Zayed, Y.; Peng, C. Overview of MicroRNA Biogenesis, Mechanisms of Actions, and Circulation. Front. Endocrinol. 2018, 9, 402. [CrossRef] [PubMed]

5. Behm-Ansmant, I.; Rehwinkel, J.; Doerks, T.; Stark, A.; Bork, P.; Izaurralde, E. mRNA degradation by miRNAs and GW182 requires both CCR4:NOT deadenylase and DCP1:DCP2 decapping complexes. Genes Dev. 2006, 20, 1885-1898. [CrossRef]

6. Braun, J.E.; Truffault, V.; Boland, A.; Huntzinger, E.; Chang, C.T.; Haas, G.; Weichenrieder, O.; Coles, M.; Izaurralde, E. A direct interaction between DCP1 and XRN1 couples mRNA decapping to 5' exonucleolytic degradation. Nat. Struct. Mol. Biol. 2012, 19, 1324-1331. [CrossRef]

7. Eichhorn, S.W.; Guo, H.; McGeary, S.E.; Rodriguez-Mias, R.A.; Shin, C.; Baek, D.; Hsu, S.H.; Ghoshal, K.; Villen, J.; Bartel, D.P. mRNA destabilization is the dominant effect of mammalian microRNAs by the time substantial repression ensues. Mol. Cell 2014, 56, 104-115. [CrossRef]

8. Fukao, A.; Mishima, Y.; Takizawa, N.; Oka, S.; Imataka, H.; Pelletier, J.; Sonenberg, N.; Thoma, C.; Fujiwara, T. MicroRNAs trigger dissociation of eIF4AI and eIF4AII from target mRNAs in humans. Mol. Cell 2014, 56, 79-89. [CrossRef]

9. Gebert, L.F.R.; MacRae, I.J. Regulation of microRNA function in animals. Nat. Rev. Mol. Cell Biol. 2019, 20, 21-37. [CrossRef]

10. Brummer, A.; Hausser, J. MicroRNA binding sites in the coding region of mRNAs: Extending the repertoire of post-transcriptional gene regulation. Bioessays 2014, 36, 617-626. [CrossRef]

11. Cardinali, B.; Cappella, M.; Provenzano, C.; Garcia-Manteiga, J.M.; Lazarevic, D.; Cittaro, D.; Martelli, F.; Falcone, G. MicroRNA-222 regulates muscle alternative splicing through Rbm24 during differentiation of skeletal muscle cells. Cell Death Dis. 2016, 7, e2086. [CrossRef] [PubMed] 
12. Spengler, R.M.; Zhang, X.; Cheng, C.; McLendon, J.M.; Skeie, J.M.; Johnson, F.L.; Davidson, B.L.; Boudreau, R.L. Elucidation of transcriptome-wide microRNA binding sites in human cardiac tissues by Ago2 HITS-CLIP. Nucleic Acids Res. 2016, 44, 7120-7131. [CrossRef] [PubMed]

13. Vasudevan, S.; Steitz, J.A. AU-rich-element-mediated upregulation of translation by FXR1 and Argonaute 2. Cell 2007, 128, 1105-1118. [CrossRef] [PubMed]

14. Truesdell, S.S.; Mortensen, R.D.; Seo, M.; Schroeder, J.C.; Lee, J.H.; LeTonqueze, O.; Vasudevan, S. MicroRNA-mediated mRNA Translation Activation in Quiescent Cells and Oocytes Involves Recruitment of a Nuclear microRNP. Sci. Rep. 2012, 2, 1-12. [CrossRef]

15. Henke, J.I.; Goergen, D.; Zheng, J.; Song, Y.; Schuttler, C.G.; Fehr, C.; Junemann, C.; Niepmann, M. microRNA-122 stimulates translation of hepatitis C virus RNA. Embo J. 2008, 27, 3300-3310. [CrossRef]

16. Machlin, E.S.; Sarnow, P.; Sagan, S.M. Masking the $5^{\prime}$ terminal nucleotides of the hepatitis $C$ virus genome by an unconventional microRNA-target RNA complex. Proc. Natl. Acad. Sci. USA 2011, 108, 3193-3198. [CrossRef]

17. Shimakami, T.; Yamane, D.; Jangra, R.K.; Kempf, B.J.; Spaniel, C.; Barton, D.J.; Lemon, S.M. Stabilization of hepatitis C virus RNA by an Ago2-miR-122 complex. Proc. Natl. Acad. Sci. USA 2012, 109, 941-946. [CrossRef]

18. Valinezhad Orang, A.; Safaralizadeh, R.; Kazemzadeh-Bavili, M. Mechanisms of miRNA-Mediated Gene Regulation from Common Downregulation to mRNA-Specific Upregulation. Int. J. Genom. 2014, 2014, 970607. [CrossRef]

19. Orom, U.A.; Nielsen, F.C.; Lund, A.H. MicroRNA-10a binds the 5'UTR of ribosomal protein mRNAs and enhances their translation. Mol. Cell 2008, 30, 460-471. [CrossRef]

20. Tsai, N.P.; Lin, Y.L.; Wei, L.N. MicroRNA mir-346 targets the 5'-untranslated region of receptor-interacting protein 140 (RIP140) mRNA and up-regulates its protein expression. Biochem. J. 2009, 424, 411-418. [CrossRef]

21. Schraivogel, D.; Meister, G. Import routes and nuclear functions of Argonaute and other small RNA-silencing proteins. Trends Biochem. Sci. 2014, 39, 420-431. [CrossRef] [PubMed]

22. Liu, H.; Lei, C.; He, Q.; Pan, Z.; Xiao, D.; Tao, Y. Nuclear functions of mammalian MicroRNAs in gene regulation, immunity and cancer. Mol. Cancer 2018, 17, 64. [CrossRef] [PubMed]

23. Schraivogel, D.; Schindler, S.G.; Danner, J.; Kremmer, E.; Pfaff, J.; Hannus, S.; Depping, R.; Meister, G. Importin- $\beta$ facilitates nuclear import of human GW proteins and balances cytoplasmic gene silencing protein levels. Nucleic Acids Res. 2015, 43, 7447-7461. [CrossRef] [PubMed]

24. Chaston, J.J.; Stewart, A.G.; Christie, M. Structural characterisation of TNRC6A nuclear localisation signal in complex with importin-alpha. PLoS ONE 2017, 12, e0183587. [CrossRef]

25. Nishi, K.; Nishi, A.; Nagasawa, T.; Ui-Tei, K. Human TNRC6A is an Argonaute-navigator protein for microRNA-mediated gene silencing in the nucleus. RNA 2013, 19, 17-35. [CrossRef]

26. Wei, Y.; Li, L.; Wang, D.; Zhang, C.Y.; Zen, K. Importin 8 regulates the transport of mature microRNAs into the cell nucleus. J. Biol. Chem. 2014, 289, 10270-10275. [CrossRef]

27. Hwang, H.; Wentzel, E.; Mendell, J. A hexanucleotide element directs microRNA nuclear import. Science 2007, 315. [CrossRef]

28. Jeffries, C.D.; Fried, H.M.; Perkins, D.O. Nuclear and cytoplasmic localization of neural stem cell microRNAs. RNA 2011, 17, 675-686. [CrossRef]

29. Turunen, T.A.; Roberts, T.C.; Laitinen, P.; Väänänen, M.-A.; Korhonen, P.; Malm, T.; Ylä-Herttuala, S.; Turunen, M.P. Changes in nuclear and cytoplasmic microRNA distribution in response to hypoxic stress. Sci. Rep. 2019, 9, 1-12. [CrossRef]

30. Li, L.C. Small RNA-Guided Transcriptional Gene Activation (RNAa) in Mammalian Cells. Adv. Exp. Med. Biol. 2017, 983, 1-20. [CrossRef]

31. Roberts, T.C. The MicroRNA Biology of the Mammalian Nucleus. Mol. Ther. Nucleic Acids 2014, 3, e188. [CrossRef] [PubMed]

32. Benhamed, M.; Herbig, U.; Ye, T.; Dejean, A.; Bischof, O. Senescence is an endogenous trigger for microRNA-directed transcriptional gene silencing in human cells. Nat. Cell Biol. 2012, 14, 266-275. [CrossRef] [PubMed]

33. Miao, L.; Yao, H.; Li, C.; Pu, M.; Yao, X.; Yang, H.; Qi, X.; Ren, J.; Wang, Y. A dual inhibition: microRNA-552 suppresses both transcription and translation of cytochrome P450 2E1. Biochim. Biophys. Acta 2016, 1859, 650-662. [CrossRef] 
34. Zhang, Y.; Fan, M.; Zhang, X.; Huang, F.; Wu, K.; Zhang, J.; Liu, J.; Huang, Z.; Luo, H.; Tao, L.; et al. Cellular microRNAs up-regulate transcription via interaction with promoter TATA-box motifs. RNA 2014, 20, 1878-1889. [CrossRef]

35. Huang, V.; Place, R.F.; Portnoy, V.; Wang, J.; Qi, Z.; Jia, Z.; Yu, A.; Shuman, M.; Yu, J.; Li, L.C. Upregulation of Cyclin B1 by miRNA and its implications in cancer. Nucleic Acids Res. 2012, 40, 1695-1707. [CrossRef] [PubMed]

36. Xiao, M.; Li, J.; Li, W.; Wang, Y.; Wu, F.; Xi, Y.; Zhang, L.; Ding, C.; Luo, H.; Li, Y.; et al. MicroRNAs activate gene transcription epigenetically as an enhancer trigger. RNA Biol. 2017, 14, 1326-1334. [CrossRef] [PubMed]

37. Kim, D.H.; Saetrom, P.; Snove, O., Jr.; Rossi, J.J. MicroRNA-directed transcriptional gene silencing in mammalian cells. Proc. Natl. Acad. Sci. USA 2008, 105, 16230-16235. [CrossRef]

38. Gonzalez, S.; Pisano, D.G.; Serrano, M. Mechanistic principles of chromatin remodeling guided by siRNAs and miRNAs. Cell Cycle 2008, 7, 2601-2608. [CrossRef]

39. Zardo, G.; Ciolfi, A.; Vian, L.; Starnes, L.; Billi, M.; Racanicchi, S.; Maresca, C.; Fazi, F.; Travaglini, L.; Noguera, N.; et al. Polycombs and microRNA-223 regulate human granulopoiesis by transcriptional control of target gene expression. Blood 2012, 119. [CrossRef]

40. Tan, Y.; Zhang, B.; Wu, T.; Skogerbø, G.; Zhu, X.; Guo, X.; He, S.; Chen, R. Transcriptional inhibiton of Hoxd4 expression by miRNA-10a in human breast cancer cells. BMC Mol. Biol. 2009, 10,1-9. [CrossRef]

41. Ramchandran, R.; Chaluvally-Raghavan, P. miRNA-Mediated RNA Activation in Mammalian Cells. Adv. Exp. Med. Biol. 2017, 983, 81-89. [CrossRef] [PubMed]

42. Catalanotto, C.; Cogoni, C.; Zardo, G. MicroRNA in Control of Gene Expression: An Overview of Nuclear Functions. Int. J. Mol. Sci. 2016, 17, 1712. [CrossRef] [PubMed]

43. Place, R.F.; Li, L.C.; Pookot, D.; Noonan, E.J.; Dahiya, R. MicroRNA-373 induces expression of genes with complementary promoter sequences. Proc. Natl. Acad. Sci. USA 2008, 105, 1608-1613. [CrossRef] [PubMed]

44. Majid, S.; Dar, A.A.; Saini, S.; Yamamura, S.; Hirata, H.; Tanaka, Y.; Deng, G.; Dahiya, R. MicroRNA-205directed transcriptional activation of tumor suppressor genes in prostate cancer. Cancer 2010, 116, 5637-5649. [CrossRef]

45. Tang, R.; Li, L.; Zhu, D.; Hou, D.; Cao, T.; Gu, H.; Zhang, J.; Chen, J.; Zhang, C.Y.; Zen, K. Mouse miRNA-709 directly regulates miRNA-15a/16-1 biogenesis at the posttranscriptional level in the nucleus: Evidence for a microRNA hierarchy system. Cell Res. 2012, 22, 504-515. [CrossRef]

46. Leucci, E.; Patella, F.; Waage, J.; Holmstrom, K.; Lindow, M.; Porse, B.; Kauppinen, S.; Lund, A.H. microRNA-9 targets the long non-coding RNA MALAT1 for degradation in the nucleus. Sci. Rep. 2013, 3, 2535. [CrossRef]

47. Liang, W.C.; Fu, W.M.; Wang, Y.B.; Sun, Y.X.; Xu, L.L.; Wong, C.W.; Chan, K.M.; Li, G.; Waye, M.M.; Zhang, J.F. H19 activates Wnt signaling and promotes osteoblast differentiation by functioning as a competing endogenous RNA. Sci. Rep. 2016, 6, 20121. [CrossRef]

48. Fasanaro, P.; Greco, S.; Lorenzi, M.; Pescatori, M.; Brioschi, M.; Kulshreshtha, R.; Banfi, C.; Stubbs, A.; Calin, G.A.; Ivan, M.; et al. An integrated approach for experimental target identification of hypoxia-induced miR-210. J. Biol. Chem. 2009, 284, 35134-35143. [CrossRef]

49. Hansen, T.B.; Wiklund, E.D.; Bramsen, J.B.; Villadsen, S.B.; Statham, A.L.; Clark, S.J.; Kjems, J. miRNA-dependent gene silencing involving Ago2-mediated cleavage of a circular antisense RNA. Embo J. 2011, 30, 4414-4422. [CrossRef]

50. Allo, M.; Buggiano, V.; Fededa, J.P.; Petrillo, E.; Schor, I.; de la Mata, M.; Agirre, E.; Plass, M.; Eyras, E.; Elela, S.A.; et al. Control of alternative splicing through siRNA-mediated transcriptional gene silencing. Nat. Struct. Mol. Biol. 2009, 16, 717-724. [CrossRef]

51. Ameyar-Zazoua, M.; Rachez, C.; Souidi, M.; Robin, P.; Fritsch, L.; Young, R.; Morozova, N.; Fenouil, R.; Descostes, N.; Andrau, J.C.; et al. Argonaute proteins couple chromatin silencing to alternative splicing. Nat. Struct. Mol. Biol. 2012, 19, 998-1004. [CrossRef]

52. Chi, S.W.; Zang, J.B.; Mele, A.; Darnell, R.B. Argonaute HITS-CLIP decodes microRNA-mRNA interaction maps. Nature 2009, 460, 479-486. [CrossRef] [PubMed]

53. Boudreau, R.L.; Jiang, P.; Gilmore, B.L.; Spengler, R.M.; Tirabassi, R.; Nelson, J.A.; Ross, C.A.; Xing, Y.; Davidson, B.L. Transcriptome-wide discovery of microRNA binding sites in human brain. Neuron 2014, 81, 294-305. [CrossRef] [PubMed]

54. Castel, S.E.; Martienssen, R.A. RNA interference in the nucleus: Roles for small RNAs in transcription, epigenetics and beyond. Nat. Rev. Genet. 2013, 14, 100-112. [CrossRef] [PubMed] 
55. Liu, J.; Hu, J.; Hicks, J.A.; Prakash, T.P.; Corey, D.R. Modulation of Splicing by Single-Stranded Silencing RNAs. Nucleic Acid Ther. 2015, 25, 113-120. [CrossRef]

56. Sadakierska-Chudy, A.; Kostrzewa, R.M.; Filip, M. A comprehensive view of the epigenetic landscape part I: DNA methylation, passive and active DNA demethylation pathways and histone variants. Neurotox. Res. 2015, 27, 84-97. [CrossRef]

57. Sadakierska-Chudy, A.; Filip, M. A comprehensive view of the epigenetic landscape. Part II: Histone post-translational modification, nucleosome level, and chromatin regulation by ncRNAs. Neurotox. Res. 2015, 27, 172-197. [CrossRef]

58. Feinberg, A.P.; Vogelstein, B. Hypomethylation distinguishes genes of some human cancers from their normal counterparts. Nature 2020, 301, 89-92. [CrossRef]

59. Dai, E.; Yu, X.; Zhang, Y.; Meng, F.; Wang, S.; Liu, X.; Liu, D.; Wang, J.; Li, X.; Jiang, W. EpimiR: A database of curated mutual regulation between miRNAs and epigenetic modifications. Database 2014, 2014, bau023. [CrossRef]

60. Malumbres, M. miRNAs and cancer: An epigenetics view. Mol. Asp. Med. 2013, 34, 863-874. [CrossRef]

61. Memari, F.; Joneidi, Z.; Taheri, B.; Aval, S.F.; Roointan, A.; Zarghami, N. Epigenetics and Epi-miRNAs: Potential markers/therapeutics in leukemia. Biomed. Pharmacother. 2018, 106, 1668-1677. [CrossRef] [PubMed]

62. Svoronos, A.A.; Engelman, D.M.; Slack, F.J. OncomiR or Tumor Suppressor? The Duplicity of MicroRNAs in Cancer. Cancer Res. 2016, 76, 3666-3670. [CrossRef] [PubMed]

63. Oliveto, S.; Mancino, M.; Manfrini, N.; Biffo, S. Role of microRNAs in translation regulation and cancer. World J. Biol. Chem. 2017, 8, 45-56. [CrossRef]

64. Humphries, B.; Wang, Z.; Yang, C. MicroRNA Regulation of Epigenetic Modifiers in Breast Cancer. Cancers 2019, 11, 897. [CrossRef] [PubMed]

65. Corra, F.; Agnoletto, C.; Minotti, L.; Baldassari, F.; Volinia, S. The Network of Non-coding RNAs in Cancer Drug Resistance. Front. Oncol. 2018, 8, 327. [CrossRef] [PubMed]

66. Calin, G.A.; Croce, C.M. MicroRNA signatures in human cancers. Nat. Rev. Cancer 2006, 6, 857-866. [CrossRef]

67. Carvalho, J.; van Grieken, N.C.; Pereira, P.M.; Sousa, S.; Tijssen, M.; Buffart, T.E.; Diosdado, B.; Grabsch, H.; Santos, M.A.; Meijer, G.; et al. Lack of microRNA-101 causes E-cadherin functional deregulation through EZH2 up-regulation in intestinal gastric cancer. J. Pathol. 2012, 228, 31-44. [CrossRef]

68. Fabbri, M.; Garzon, R.; Cimmino, A.; Liu, Z.; Zanesi, N.; Callegari, E.; Liu, S.; Alder, H.; Costinean, S.; Fernandez-Cymering, C.; et al. MicroRNA-29 family reverts aberrant methylation in lung cancer by targeting DNA methyltransferases 3A and 3B. Proc. Natl. Acad. Sci. USA 2007, 104, 15805-15810. [CrossRef]

69. Garzon, R.; Liu, S.; Fabbri, M.; Liu, Z.; Heaphy, C.E.; Callegari, E.; Schwind, S.; Pang, J.; Yu, J.; Muthusamy, N.; et al. MicroRNA-29b induces global DNA hypomethylation and tumor suppressor gene reexpression in acute myeloid leukemia by targeting directly DNMT3A and 3B and indirectly DNMT1. Blood 2009, 113, 6411-6418. [CrossRef]

70. Amodio, N.; Rossi, M.; Raimondi, L.; Pitari, M.R.; Botta, C.; Tagliaferri, P.; Tassone, P. miR-29s: A family of epi-miRNAs with therapeutic implications in hematologic malignancies. Oncotarget 2015, 6, 12837-12861. [CrossRef]

71. Lombard, A.P.; Mooso, B.A.; Libertini, S.J.; Lim, R.M.; Nakagawa, R.M.; Vidallo, K.D.; Costanzo, N.C.; Ghosh, P.M.; Mudryj, M. miR-148a dependent apoptosis of bladder cancer cells is mediated in part by the epigenetic modifier DNMT1. Mol. Carcinog. 2016, 55, 757-767. [CrossRef] [PubMed]

72. Iliopoulos, D.; Lindahl-Allen, M.; Polytarchou, C.; Hirsch, H.A.; Tsichlis, P.N.; Struhl, K. Loss of miR-200 inhibition of Suz12 leads to polycomb-mediated repression required for the formation and maintenance of cancer stem cells. Mol. Cell 2010, 39, 761-772. [CrossRef] [PubMed]

73. Ren, X.; Bai, X.; Zhang, X.; Li, Z.; Tang, L.; Zhao, X.; Ren, Y.; Wei, S.; Wang, Q.; Liu, C.; et al. Quantitative nuclear proteomics identifies that miR-137-mediated EZH2 reduction regulates resveratrol-induced apoptosis of neuroblastoma cells. Mol. Cell Proteom. 2015, 14, 316-328. [CrossRef] [PubMed]

74. Zamani, M.; Sadeghizadeh, M.; Behmanesh, M.; Najafi, F. Dendrosomal curcumin increases expression of the long non-coding RNA gene MEG3 via up-regulation of epi-miRs in hepatocellular cancer. Phytomedicine 2015, 22, 961-967. [CrossRef] 
75. Jiang, F.; Li, Y.; Mu, J.; Hu, C.; Zhou, M.; Wang, X.; Si, L.; Ning, S.; Li, Z. Glabridin inhibits cancer stem cell-like properties of human breast cancer cells: An epigenetic regulation of miR-148a/SMAd2 signaling. Mol. Carcinog. 2016, 55, 929-940. [CrossRef] [PubMed]

76. Baumann, V.; Winkler, J. miRNA-based therapies: Strategies and delivery platforms for oligonucleotide and non-oligonucleotide agents. Future Med. Chem. 2014, 6, 1967-1984. [CrossRef]

77. Kota, J.; Chivukula, R.R.; O’Donnell, K.A.; Wentzel, E.A.; Montgomery, C.L.; Hwang, H.W.; Chang, T.C.; Vivekanandan, P.; Torbenson, M.; Clark, K.R.; et al. Therapeutic microRNA delivery suppresses tumorigenesis in a murine liver cancer model. Cell 2009, 137, 1005-1017. [CrossRef]

78. Zhang, Y.; Wang, Z.; Gemeinhart, R.A. Progress in MicroRNA Delivery. J. Control. Release 2013, 172, 962-974. [CrossRef]

79. Huang, X.; Schwind, S.; Yu, B.; Santhanam, R.; Wang, H.; Hoellerbauer, P.; Mims, A.; Klisovic, R.; Walker, A.R.; Chan, K.K.; et al. Targeted delivery of microRNA-29b by transferrin-conjugated anionic lipopolyplex nanoparticles: A novel therapeutic strategy in acute myeloid leukemia. Clin. Cancer Res. 2013, 19, 2355-2367. [CrossRef]

80. Beg, M.S.; Brenner, A.J.; Sachdev, J.; Borad, M.; Kang, Y.K.; Stoudemire, J.; Smith, S.; Bader, A.G.; Kim, S.; Hong, D.S. Phase I study of MRX34, a liposomal miR-34a mimic, administered twice weekly in patients with advanced solid tumors. Investig. New Drugs 2017, 35, 180-188. [CrossRef]

81. Reid, G.; Kao, S.; Pavlakis, N.; Brahmbhatt, H.; MacDiarmid, J.; Clarke, S.; Boyer, M.; van Zandwijk, N. Clinical development of TargomiRs, a miRNA mimic-based treatment for patients with recurrent thoracic cancer. Epigenomics 2016, 8, 1079-1085. [CrossRef] [PubMed]

82. Wu, M.Y.; Fu, J.; Xiao, X.; Wu, J.; Wu, R.C. MiR-34a regulates therapy resistance by targeting HDAC1 and HDAC7 in breast cancer. Cancer Lett. 2014, 354, 311-319. [CrossRef] [PubMed]

83. Varambally, S.; Cao, Q.; Mani, R.S.; Shankar, S.; Wang, X.; Ateeq, B.; Laxman, B.; Cao, X.; Jing, X.; Ramnarayanan, K.; et al. Genomic loss of microRNA-101 leads to overexpression of histone methyltransferase EZH2 in cancer. Science 2008, 322, 1695-1699. [CrossRef] [PubMed]

84. Zhu, Y.; Yu, F.; Jiao, Y.; Feng, J.; Tang, W.; Yao, H.; Gong, C.; Chen, J.; Su, F.; Zhang, Y.; et al. Reduced miR-128 in breast tumor-initiating cells induces chemotherapeutic resistance via Bmi-1 and ABCC5. Clin. Cancer Res. 2011, 17, 7105-7115. [CrossRef] [PubMed]

85. Tang, H.; Liu, P.; Yang, L.; Xie, X.; Ye, F.; Wu, M.; Liu, X.; Chen, B.; Zhang, L. miR-185 suppresses tumor proliferation by directly targeting E2F6 and DNMT1 and indirectly upregulating BRCA1 in triple-negative breast cancer. Mol. Cancer Ther. 2014, 13, 3185-3197. [CrossRef]

86. Friedman, J.M.; Liang, G.; Liu, C.C.; Wolff, E.M.; Tsai, Y.C.; Ye, W.; Zhou, X.; Jones, P.A. The putative tumor suppressor microRNA-101 modulates the cancer epigenome by repressing the polycomb group protein EZH2. Cancer Res. 2009, 69, 2623-2629. [CrossRef]

87. Wang, X.; Wu, Q.; Xu, B.; Wang, P.; Fan, W.; Cai, Y.; Gu, X.; Meng, F. MiR-124 exerts tumor suppressive functions on the cell proliferation, motility and angiogenesis of bladder cancer by fine-tuning UHRF1. FEBS J. 2015, 282, 4376-4388. [CrossRef]

88. Guo, Y.; Ying, L.; Tian, Y.; Yang, P.; Zhu, Y.; Wang, Z.; Qiu, F.; Lin, J. miR-144 downregulation increases bladder cancer cell proliferation by targeting EZH2 and regulating Wnt signaling. FEBS J. 2013, 280, 4531-4538. [CrossRef]

89. Matsushita, R.; Yoshino, H.; Enokida, H.; Goto, Y.; Miyamoto, K.; Yonemori, M.; Inoguchi, S.; Nakagawa, M.; Seki, N. Regulation of UHRF1 by dual-strand tumor-suppressor microRNA-145 (miR-145-5p and miR-145-3p): Inhibition of bladder cancer cell aggressiveness. Oncotarget 2016, 7, 28460-28487. [CrossRef]

90. Zhu, M.; Xu, Y.; Ge, M.; Gui, Z.; Yan, F. Regulation of UHRF1 by microRNA-9 modulates colorectal cancer cell proliferation and apoptosis. Cancer Sci. 2015, 106, 833-839. [CrossRef]

91. Ng, E.K.; Tsang, W.P.; Ng, S.S.; Jin, H.C.; Yu, J.; Li, J.J.; Rocken, C.; Ebert, M.P.; Kwok, T.T.; Sung, J.J. MicroRNA-143 targets DNA methyltransferases 3A in colorectal cancer. Br. J. Cancer 2009, 101, 699-706. [CrossRef] [PubMed]

92. Wang, H.; Wu, J.; Meng, X.; Ying, X.; Zuo, Y.; Liu, R.; Pan, Z.; Kang, T.; Huang, W. MicroRNA-342 inhibits colorectal cancer cell proliferation and invasion by directly targeting DNA methyltransferase 1. Carcinogenesis 2011, 32, 1033-1042. [CrossRef] [PubMed] 
93. Konno, Y.; Dong, P.; Xiong, Y.; Suzuki, F.; Lu, J.; Cai, M.; Watari, H.; Mitamura, T.; Hosaka, M.; Hanley, S.J.; et al. MicroRNA-101 targets EZH2, MCL-1 and FOS to suppress proliferation, invasion and stem cell-like phenotype of aggressive endometrial cancer cells. Oncotarget 2014, 5, 6049-6062. [CrossRef] [PubMed]

94. Yu, X.; Jiang, X.; Li, H.; Guo, L.; Jiang, W.; Lu, S.H. miR-203 inhibits the proliferation and self-renewal of esophageal cancer stem-like cells by suppressing stem renewal factor Bmi-1. Stem Cells Dev. 2014, 23, 576-585. [CrossRef] [PubMed]

95. Cui, H.; Wang, L.; Gong, P.; Zhao, C.; Zhang, S.; Zhang, K.; Zhou, R.; Zhao, Z.; Fan, H. Deregulation between $\mathrm{miR}-29 \mathrm{~b} / \mathrm{c}$ and DNMT3A is associated with epigenetic silencing of the CDH1 gene, affecting cell migration and invasion in gastric cancer. PLOS ONE 2015, 10, e0123926. [CrossRef]

96. Zhou, L.; Zhao, X.; Han, Y.; Lu, Y.; Shang, Y.; Liu, C.; Li, T.; Jin, Z.; Fan, D.; Wu, K. Regulation of UHRF1 by $\mathrm{miR}-146 \mathrm{a} / \mathrm{b}$ modulates gastric cancer invasion and metastasis. FASEB J. 2013, 27, 4929-4939. [CrossRef]

97. Yan, J.; Guo, X.; Xia, J.; Shan, T.; Gu, C.; Liang, Z.; Zhao, W.; Jin, S. MiR-148a regulates MEG3 in gastric cancer by targeting DNA methyltransferase 1. Med. Oncol. 2014, 31, 879. [CrossRef]

98. Ren, J.; Huang, H.J.; Gong, Y.; Yue, S.; Tang, L.M.; Cheng, S.Y. MicroRNA-206 suppresses gastric cancer cell growth and metastasis. Cell Biosci. 2014, 4, 26. [CrossRef]

99. Godlewski, J.; Nowicki, M.O.; Bronisz, A.; Williams, S.; Otsuki, A.; Nuovo, G.; Raychaudhury, A.; Newton, H.B.; Chiocca, E.A.; Lawler, S. Targeting of the Bmi-1 oncogene/stem cell renewal factor by microRNA-128 inhibits glioma proliferation and self-renewal. Cancer Res. 2008, 68, 9125-9130. [CrossRef]

100. Peruzzi, P.; Bronisz, A.; Nowicki, M.O.; Wang, Y.; Ogawa, D.; Price, R.; Nakano, I.; Kwon, C.H.; Hayes, J.; Lawler, S.E.; et al. MicroRNA-128 coordinately targets Polycomb Repressor Complexes in glioma stem cells. Neuro Oncol. 2013, 15, 1212-1224. [CrossRef]

101. Nohata, N.; Hanazawa, T.; Kinoshita, T.; Inamine, A.; Kikkawa, N.; Itesako, T.; Yoshino, H.; Enokida, H.; Nakagawa, M.; Okamoto, Y.; et al. Tumour-suppressive microRNA-874 contributes to cell proliferation through targeting of histone deacetylase 1 in head and neck squamous cell carcinoma. Br. J. Cancer 2013, 108, 1648-1658. [CrossRef] [PubMed]

102. Braconi, C.; Huang, N.; Patel, T. MicroRNA-dependent regulation of DNA methyltransferase-1 and tumor suppressor gene expression by interleukin-6 in human malignant cholangiocytes. Hepatology 2010, 51, 881-890. [CrossRef] [PubMed]

103. Zhang, J.; Yang, Y.; Yang, T.; Liu, Y.; Li, A.; Fu, S.; Wu, M.; Pan, Z.; Zhou, W. microRNA-22, downregulated in hepatocellular carcinoma and correlated with prognosis, suppresses cell proliferation and tumourigenicity. Br. J. Cancer 2010, 103, 1215-1220. [CrossRef]

104. Noh, J.H.; Chang, Y.G.; Kim, M.G.; Jung, K.H.; Kim, J.K.; Bae, H.J.; Eun, J.W.; Shen, Q.; Kim, S.J.; Kwon, S.H.; et al. MiR-145 functions as a tumor suppressor by directly targeting histone deacetylase 2 in liver cancer. Cancer Lett. 2013, 335, 455-462. [CrossRef]

105. Yuan, J.H.; Yang, F.; Chen, B.F.; Lu, Z.; Huo, X.S.; Zhou, W.P.; Wang, F.; Sun, S.H. The histone deacetylase 4/SP1/microrna-200a regulatory network contributes to aberrant histone acetylation in hepatocellular carcinoma. Hepatology 2011, 54, 2025-2035. [CrossRef]

106. Garzon, R.; Heaphy, C.E.; Havelange, V.; Fabbri, M.; Volinia, S.; Tsao, T.; Zanesi, N.; Kornblau, S.M.; Marcucci, G.; Calin, G.A.; et al. MicroRNA 29b functions in acute myeloid leukemia. Blood 2009, 114, 5331-5341. [CrossRef] [PubMed]

107. Li, Y.; Gao, L.; Luo, X.; Wang, L.; Gao, X.; Wang, W.; Sun, J.; Dou, L.; Li, J.; Xu, C.; et al. Epigenetic silencing of microRNA-193a contributes to leukemogenesis in $\mathrm{t}(8 ; 21)$ acute myeloid leukemia by activating the PTEN/PI3K signal pathway. Blood 2013, 121, 499-509. [CrossRef]

108. Nishioka, C.; Ikezoe, T.; Yang, J.; Nobumoto, A.; Tsuda, M.; Yokoyama, A. Downregulation of miR-217 correlates with resistance of $\mathrm{Ph}(+)$ leukemia cells to ABL tyrosine kinase inhibitors. Cancer Sci. 2014, 105, 297-307. [CrossRef]

109. Shen, J.Z.; Zhang, Y.Y.; Fu, H.Y.; Wu, D.S.; Zhou, H.R. Overexpression of microRNA-143 inhibits growth and induces apoptosis in human leukemia cells. Oncol. Rep. 2014, 31, 2035-2042. [CrossRef]

110. Yu, T.; Li, J.; Yan, M.; Liu, L.; Lin, H.; Zhao, F.; Sun, L.; Zhang, Y.; Cui, Y.; Zhang, F.; et al. MicroRNA-193a-3p and -5p suppress the metastasis of human non-small-cell lung cancer by downregulating the ERBB4/PIK3R3/mTOR/S6K2 signaling pathway. Oncogene 2015, 34, 413-423. [CrossRef] 
111. Sander, S.; Bullinger, L.; Klapproth, K.; Fiedler, K.; Kestler, H.A.; Barth, T.F.; Moller, P.; Stilgenbauer, S.; Pollack, J.R.; Wirth, T. MYC stimulates EZH2 expression by repression of its negative regulator miR-26a. Blood 2008, 112, 4202-4212. [CrossRef] [PubMed]

112. Liu, S.; Tetzlaff, M.T.; Cui, R.; Xu, X. miR-200c inhibits melanoma progression and drug resistance through down-regulation of BMI-1. Am. J. Pathol. 2012, 181, 1823-1835. [CrossRef] [PubMed]

113. Neo, W.H.; Yap, K.; Lee, S.H.; Looi, L.S.; Khandelia, P.; Neo, S.X.; Makeyev, E.V.; Su, I.H. MicroRNA miR-124 controls the choice between neuronal and astrocyte differentiation by fine-tuning Ezh2 expression. J. Biol. Chem. 2014, 289, 20788-20801. [CrossRef] [PubMed]

114. Althoff, K.; Beckers, A.; Odersky, A.; Mestdagh, P.; Koster, J.; Bray, I.M.; Bryan, K.; Vandesompele, J.; Speleman, F.; Stallings, R.L.; et al. MiR-137 functions as a tumor suppressor in neuroblastoma by downregulating KDM1A. Int. J. Cancer 2013, 133, 1064-1073. [CrossRef]

115. Das, S.; Foley, N.; Bryan, K.; Watters, K.M.; Bray, I.; Murphy, D.M.; Buckley, P.G.; Stallings, R.L. MicroRNA mediates DNA demethylation events triggered by retinoic acid during neuroblastoma cell differentiation. Cancer Res. 2010, 70, 7874-7881. [CrossRef]

116. Zhang, D.; Ni, Z.; Xu, X.; Xiao, J. MiR-32 functions as a tumor suppressor and directly targets EZH2 in human oral squamous cell carcinoma. Med. Sci. Monit. 2014, 20, 2527-2535. [CrossRef]

117. Bhattacharya, R.; Nicoloso, M.; Arvizo, R.; Wang, E.; Cortez, A.; Rossi, S.; Calin, G.A.; Mukherjee, P. MiR-15a and MiR-16 control Bmi-1 expression in ovarian cancer. Cancer Res. 2009, 69, 9090-9095. [CrossRef]

118. Xiang, Y.; Ma, N.; Wang, D.; Zhang, Y.; Zhou, J.; Wu, G.; Zhao, R.; Huang, H.; Wang, X.; Qiao, Y.; et al. MiR-152 and miR-185 co-contribute to ovarian cancer cells cisplatin sensitivity by targeting DNMT1 directly: A novel epigenetic therapy independent of decitabine. Oncogene 2014, 33, 378-386. [CrossRef]

119. Azizi, M.; Teimoori-Toolabi, L.; Arzanani, M.K.; Azadmanesh, K.; Fard-Esfahani, P.; Zeinali, S. MicroRNA-148b and microRNA-152 reactivate tumor suppressor genes through suppression of DNA methyltransferase-1 gene in pancreatic cancer cell lines. Cancer Biol. Ther. 2014, 15, 419-427. [CrossRef]

120. Xue, G.; Ren, Z.; Chen, Y.; Zhu, J.; Du, Y.; Pan, D.; Li, X.; Hu, B. A feedback regulation between miR-145 and DNA methyltransferase $3 \mathrm{~b}$ in prostate cancer cell and their responses to irradiation. Cancer Lett. 2015, 361, 121-127. [CrossRef]

121. Noonan, E.J.; Place, R.F.; Pookot, D.; Basak, S.; Whitson, J.M.; Hirata, H.; Giardina, C.; Dahiya, R. miR-449a targets HDAC-1 and induces growth arrest in prostate cancer. Oncogene 2009, 28, 1714-1724. [CrossRef] [PubMed]

122. Goto, Y.; Kurozumi, A.; Nohata, N.; Kojima, S.; Matsushita, R.; Yoshino, H.; Yamazaki, K.; Ishida, Y.; Ichikawa, T.; Naya, Y.; et al. The microRNA signature of patients with sunitinib failure: Regulation of UHRF1 pathways by microRNA-101 in renal cell carcinoma. Oncotarget 2016, 7, 59070-59086. [CrossRef] [PubMed]

123. Wang, H.; Garzon, R.; Sun, H.; Ladner, K.J.; Singh, R.; Dahlman, J.; Cheng, A.; Hall, B.M.; Qualman, S.J.; Chandler, D.S.; et al. NF-kappaB-YY1-miR-29 regulatory circuitry in skeletal myogenesis and rhabdomyosarcoma. Cancer Cell 2008, 14, 369-381. [CrossRef]

124. Chen, B.F.; Suen, Y.K.; Gu, S.; Li, L.; Chan, W.Y. A miR-199a/miR-214 self-regulatory network via PSMD10, TP53 and DNMT1 in testicular germ cell tumor. Sci. Rep. 2014, 4, 6413. [CrossRef] [PubMed]

125. Roccaro, A.M.; Sacco, A.; Jia, X.; Azab, A.K.; Maiso, P.; Ngo, H.T.; Azab, F.; Runnels, J.; Quang, P.; Ghobrial, I.M. microRNA-dependent modulation of histone acetylation in Waldenstrom macroglobulinemia. Blood 2010, 116, 1506-1514. [CrossRef] [PubMed]

(C) 2020 by the author. Licensee MDPI, Basel, Switzerland. This article is an open access article distributed under the terms and conditions of the Creative Commons Attribution (CC BY) license (http://creativecommons.org/licenses/by/4.0/). 